\title{
SENIOR EXECUTIVES' IT MANAGEMENT RESPONSIBILITIES: SERIOUS IT-RELATED DEFICIENCIES AND CEO/CFO TURNOVER ${ }^{1}$
}

\author{
Adi Masli \\ School of Business, University of Kansas, 350-N Summerfield, 1300 Sunnyside Avenue, \\ Lawrence, KS 6604590089 U.S.A. \{amasli@ku.edu\} \\ Vernon J. Richardson \\ Sam M. Walton College of Business, University of Arkansas, Fayetteville, AR 02452 U.S.A. \{vrichardson@walton.uark.edu\} \\ and Xi'an Jiaotong Liverpool University, Suzhou, Jiangsu, CHINA \{Vernon.Richardson@xitlu.edu.cn\} \\ Marcia Weidenmier Watson \\ Belk College of Business, University of North Carolina at Charlotte, 9201 University City Boulevard, \\ Charlotte, NC 28223-0001 U.S.A. \{mwatson40@uncc.edu\} \\ Robert W. Zmud \\ Price College of Business, University of Oklahoma, 307 W. Brooks, \\ Norman, OK 73019 U.S.A. \{rzmud@ou.edu\}
}

While the information systems scholarly and practice literatures both stress the importance of senior executive engagement with IT management, the recommendations for doing so remain, at best, limited and general. Examining the influence of serious IT-related deficiencies on CEO/CFO turnover within the post-SOXfinancial reporting context, specific CEO/CFO IT management responsibilities are identified: CEOs are shown to be held accountable for global IT management responsibilities, and CFOs are shown to be held accountable for demand-side IT management responsibilities. Implications for information systems research, management research, and information systems practice are provided.

Keywords: IT management, executive responsibilities, managerial delegation, executive turnover

If war is too important to leave to the generals, the deployment of information technology is far too important, in 1988, to be left to information technologists.

John F. Rockart (1988, p. 60)

\footnotetext{
${ }^{1}$ Sue Brown was the accepting senior editor for this paper. J. J. Po-An Hsieh served as the associate editor.

The appendices for this paper are located in the "Online Supplements" section of the MIS Quarterly's website (http://www.misq.org).
} 


\section{Introduction}

Once seen as a relatively isolated technical function within firms, the information technology (IT) management realm has become a broad-ranging domain involving sophisticated technical and managerial capabilities, multimillion dollar budgets, and far-reaching implications for business strategies and business operations (Chatterjee et al. 2001; Feeney and Willcocks 1998; ITGI 2005, 2008; Nolan 2012). Recognition of the strategic and operational importance of IT has led, for more than 25 years, thought-leaders to call for firms' most senior executives to engage personally with IT management (Bensaou and Earl 1998; Boynton et al. 1991; Feeney et al. 1992; Jarvenpaa and Ives 1991; Rockart 1988).

Indeed, considerable research has examined senior executives' engagement in IT management activities (e.g., Jarvenpaa and Ives 1991; Kearns and Sabherwal 2007; Liang et al. 2007; Purvis et al. 2001; Sharma and Yetton 2003). Much of this research has, implicitly if not explicitly, applied an upper echelons lens (Carpenter et al. 2004; Hambrick 2007) emphasizing the development of structural, cognitive, and relational social capitals (Preston and Karahanna 2009) among senior IT executives, such as the chief information officer (CIO), and other senior executives, such as the chief executive officer (CEO) and the chief financial officer (CFO). Simplifying very sophisticated ideas, the logic underlying this body of research (e.g., Armstrong and Sambamurthy 1999; Banker et al. 2011; Preston and Karahanna 2009) is: The greater a firm's senior executives' shared knowledge about IT (i.e., about the roles served by IT in maintaining/enhancing the firm's competitiveness and about IT management) and the greater these executives' mutual trust, the greater is the likelihood that the firm will be successful in applying IT.

Still, this body of research has tended to describe senior executives' engagement in IT management quite generically, typically applying abstract concepts (e.g., belief structures, symbolic actions, meta-structuring actions, etc.). In particular, little is known about which senior executives should engage with which IT management activities. Further, as insightfully pointed out by Nolan (2012, p. 99) after examining IT management challenges associated with Boeing's 787 design and production program, this lack of specificity combined with the pervasiveness of IT in today's firms introduces significant managerial challenges:

IT is everywhere (mostly good) and nowhere (the bad). IT is everywhere in that it is deeply intertwined in just about everything Boeing does. IT is nowhere in that IT leadership is dissipated and fragmented throughout the Boeing Corporation, similar to other global corporations....This is a particularly difficult issue for current corporate CIO's whose direct responsibility for IT leadership has shifted from a direct responsibility to a fiduciary responsibility similar to CFO leadership. While neither the CFO nor CIO has direct control over the corporation's money assets or information assets, both are responsible for the overall effective management of the respective assets.

This situation is only exacerbated when organizations' most senior executives choose to delegate most, if not all, IT management responsibilities to a subordinate specialist, such as the CIO.

Why do firms' senior executives choose to delegate IT management responsibilities to subordinate specialists? Given the demands of their positions, senior executives have limited time available to devote to any single area of responsibility (Davenport and Beck 2013). These executives' attention deficits along with the technologically sophisticated nature of IT management have prompted many, if not most, firms' top management teams to delegate much, if not most, IT management responsibilities to subordinate specialists (Bensaou and Earl 1998; Feld and Stoddard 2004; Mitra et al. 2011; Sondergaard 2014).

Delegating a managerial responsibility to a subordinate, however, does not absolve the delegating manager from being held accountable if and when delegated responsibilities are poorly handled (Sinclair 1995). If serious IT deficiencies arise that threaten a firm's success or legitimacy, someone will likely be held accountable and suffer negative consequences. Senior executives would thus benefit from knowing the specific IT management responsibilities for which they are likely to be held accountable if poor IT-related outcomes were to materialize. This study's research question addresses this issue: For which IT management responsibilities are particular senior executives held accountable for serious IT deficiencies?

Focusing on the Sarbanes-Oxley (SOX) financial reporting context, we develop research hypotheses relating the reporting of serious IT deficiencies with senior executive (i.e., CEO and CFO) turnover and then assess these hypotheses via probit analysis, exploiting the explicitness by which the SOX Act of 2002 specifies CEO and CFO accountabilities. In doing so, we make two contributions to information systems research. First, given empirical findings demonstrating that particular senior executives (i.e., the $\mathrm{CEO}, \mathrm{CFO}$, and $\mathrm{CIO}$ ) are held accountable for specific IT management responsibilities (respectively, global, demand-side, and supply-side), we argue that IT management is a polycentric rather than monocentric activity system. Second, we extrapolate from 
our findings to provide a fresh gestalt of IT management for firms characterized by a pervasiveness in IT deployment.

Our study also makes two contributions to the management literature. First, we extend research by Arthaud-Day et al. (2006) to further reduce the causal ambiguity that has enveloped empirical findings regarding the relationship between firm performance and executive turnover (e.g., Finkelstein et al. 2009; Wisenfeld et al. 2008). Second, we provide fresh insights clarifying the nature of the accountabilities retained by delegating general managers and by delegating functional managers.

\section{Conceptual Background}

We begin by reviewing three concepts key to our theoretical arguments: senior executive roles in modern organizations, managerial delegation, and the salience of IT within the postSOX financial reporting context.

\section{Senior Executive Roles in Modern Organizations}

The upper echelons perspective (Carpenter et al. 2004; Cyert and March 1963; Hambrick 2007), the dominant theoretical lens applied in the extensive body of research examining senior executives' influences on firms' actions and outcomes, holds that (1) senior executives' influence is attributed to these individuals' power and to their serving as the organization's primary interface with the external environment and (2) senior executives' actions are based on these individuals' experiences, values, and personalities. A primary way by which executives create value (Barney 1991; Penrose 1959) is through "the creation, evaluation, manipulation, administration, and deployment of unpriced specialized scarce resource combinations" (Lippman and Rumelt 2003, p. 1069). Especially important resource combinations for today's highly competitive landscapes are those comprised of knowledge assets and innovative capabilities (Grant 1996; Kogot and Zander 1992), both of which are largely enabled through IT (El Sawy and Pavlou 2008).

Critical activities involved with knowledge-based value creation include establishing and maintaining the knowledge flows necessary for, first, assembling and, then, coordinating groupings of actors, assets, and capabilities (Zenger et al. 2011). The organization hierarchy has proven to be an especially effective means (Arrow 1974; Monteverde 1995) for facilitating the transport and use of knowledge as the hierarchy invokes managerial authority (Coase 1937), exploits the structure of the employment relationship (Barnard 1938; Ouchi 1980; Simon 1947), and both influences and leverages organization norms (Blau and Scott 1962; Dalton 1959; Kogut and Zander 1992).

The organization hierarchy formalizes managerial responsibilities and information rights (Galbraith 1973; March and Simon 1958) and establishes the managerial authority structure (Chandler 1962) for allocating scarce resources across functions and priorities (Pfeffer 1981; Pfeffer and Salancik 1978). Two distinct senior executive roles exist within organization hierarchies: a general manager role and a functional manager role (Guadelupe et al. 2014; Hambrick and Mason 1984). The responsibilities of general managers (e.g., the CEO, chief operating officer (COO), business unit president, etc.) emphasize establishing and overseeing organization-wide policies and strategies (Gore et al. 2010; Hambrick and Mason 1984) and ensuring an organization's strategic flexibility (i.e., the capability to precipitate strategic change) (Nadkarni and Hermann 2010). The responsibilities of functional managers (e.g., "front-office" positions such as the vice-presidents of sales, of marketing, of operations, etc. and "back-office" positions such as the CFO, CIO, vice president of human resources, etc.) involve these same general manager responsibilities, here limited to a specified functional domain, as well as ensuring this functional domain's operational effectiveness/efficiency.

\section{Delegation of Managerial Work Responsibilities}

A fundamental aspect of organization hierarchy design involves the apportioning of managerial responsibilities between a superior and a subordinate such that the subordinate possesses the authority to take action (for a delegated responsibility) without first obtaining the superior's approval (Yukl and Fu 1999). For example, many organizations have found it desirable to share the CEO role between a CEO and a subordinate COO (Marcel 2009). Splitting a managerial role benefits the superior in a number of ways (Boeker 1992; Hambrick et al. 2005; Leana 1986; Marcel 2009; Yukl and Fu 1999; Zenger et al. 2011): the superior's workload is reduced, available expertise and perspectives are broadened, decisions are better informed and more timely, and the superior may escape negative repercussions if problems arise with a delegated activity. Splitting a managerial role between a superior and one or more subordinates may prove especially valuable when a managerial responsibility requires specialized expertise (Gore et al. 2011; Hambrick et al. 2005; Wood et al. 1990). 
However, splitting managerial responsibilities between a superior and one or more subordinates introduces at least three potential threats for the superior. First, overseeing the subordinate can prove difficult and costly (Marcel 2009), especially when information asymmetries (Jensen and Meckling 1976) are present (e.g., when specialized expertise is held by the subordinate and when strategy formulation is separated from strategy implementation). Second, delegation increases the likelihood of organizational politics (Milgrom and Roberts 1990; Pfeffer 1981) and personal relationships (Uzzi 1996) intruding into decision processes. Third, subordinates' perceptions of a superior's fairness can negatively shape subordinate behaviors (Adams 1963).

While an executive might delegate work responsibilities, the executive is likely to retain accountability for certain of these responsibilities. Recognizing this, the mindful executive would benefit from continuing to engage, in some fashion, with certain delegated responsibilities in order to moderate associated information asymmetries (Jensen and Meckling 1976). Extant management research, however, provides little guidance for determining those delegated responsibilities for which continuing engagement would be most beneficial.

\section{Salience of IT Within the Post-SOX Financial Reporting Context}

The Sarbanes-Oxley Act of $2002(\text { SOX })^{2}$ was established to strengthen internal controls over financial reporting by U.S. public firms and, as a consequence, to increase investor and stakeholder confidence in published financial reports. Implementation of the various SOX provisions has affected decision processes within U.S. firms as well as within firms located outside the United States (Bhamornsiri et al. 2009; Prentice 2007). Specific to this study, SOX 404 requires an annual assessment by the firm's executive management and external auditor of the firm's internal controls over financial reporting (SEC 2003). Both management and external auditors must identify the presence of material weaknesses, where a

material weakness is a deficiency, or combination of deficiencies, that results in more than a remote likelihood that a material misstatement of the annual or interim financial statements will not be prevented or detected (PCAOB 2004, para. 10, p. 156). ${ }^{3}$

\footnotetext{
${ }^{2}$ Refer to Appendix A for an overview of SOX and of the SOX-related accountabilities of CEOs and CFOs.

${ }^{3}$ Note that this Auditing Standard No. 2 definition which was in effect for our
sample of firms has been superseded by Auditing Standard No. 5 which
defines a material weakness as "deficiency, or a combination of defi-
}

In other words, reported material weaknesses are indicative of a financial reporting system that fails to provide reasonable assurance regarding the reliability of the prepared financial statements in accordance with general accepted accounting procedures (GAAP). Particularly important for our study, the SOX provisions mandate that the CFO and CEO be held accountable for properly executing their fiduciary duties (i.e., establishing and maintaining their firm's internal controls regarding financial reporting) (Hoitash et al. 2012).

A firm's financial reporting systems are inextricably linked to underlying financial information systems (including enabling technology services) that capture, archive, and transform the data used in financial statement production ( $\mathrm{Li}$ et al. 2012). Serious IT deficiencies can introduce errors with regard to data and to business rules, which in turn can lead to internal control problems and to heightened complexity (hence, greater time and cost) when resolving these internal control problems (Canada et al. 2009). Such outcomes are likely to be observed regardless of whether the identified internal control problems are intentional (Palmrose et al. 2004) or unintentional (Scholz 2008). Clearly, IT "is the foundation of an effective system of [internal controls over financial reporting]" (ITGI 2004, p. 21).

Hence, an integral element of internal controls, typically not considered by extant research on financial reporting misstatements (see Eilifsen and Messier 2000), involves IT management. In practice, audits of firms' SOX compliance seek to identify both non-IT and IT material weaknesses. The distinction between these two types of material weaknesses is illustrated through an excerpt from a SOX 404 report in our data set. Here, the first bullet identifies non-IT material weaknesses and the second bullet identifies IT material weaknesses:

Controls over the preparation of interim and yearend financial statements and reconciliation of key accounts were not effective as of December 31, 2004. The following specific deficiencies were identified:

- Staffing levels in the accounting and finance functions were insufficient given the level of complexity of the Company's operations, corporate transactions, litigation, and organization structure. Roles and responsibilities within the accounting function were not clearly defined.

ciencies...such that there is a reasonable possibility that a material misstatement of the firm's financial statements will not be prevented or detected on a timely basis" (PCAOB 2007, para. A7, p. A1-43). 
- The Company's information systems were inadequate to support the complexity described above due to multiple, incompatible applications and platforms, manual interfaces and inadequate IT support staff.

While antecedents and consequences of non-IT material weaknesses have been the focus of considerable research examining the effects of the SOX regulations (e.g., Ashbaugh-Skaife et al. 2007; Beneish et al. 2008; Doyle et al. 2007; Hammersley et al. 2008), only a few empirical studies have focused on IT material weaknesses. Specifically, empirical research has observed that firms with a greater number of IT material weaknesses have more misstated accounts and more non-IT material weaknesses (Grant et al. 2008), have a greater scope of material weaknesses (Klamm and Watson 2009), take longer to correct identified material weaknesses (Klamm et al. 2012), and produce less accurate management forecasts ( $\mathrm{Li}$ et al. 2012). Such findings are indicative of a systematic relationship between IT material weaknesses (i.e., serious IT deficiencies) and the quality of firms' financial reporting systems.

\section{Development of Research Hypotheses}

Our study seeks to identify, within the post-SOX financial reporting context, IT material weaknesses that increase the likelihood of turnover for CEOs and for CFOs. We begin by developing two hypotheses that associate the likelihoods of $\mathrm{CEO} / \mathrm{CFO}$ turnover with the total number of IT material weaknesses identified in a firm's SOX 404 report. Then, we develop two more-refined hypotheses that associate the likelihoods of CEO turnover and CFO turnover, respectively, with distinct types of IT material weaknesses.

\section{Influence of IT Material Weaknesses on CEO/CFO Turnover}

A primary obligation of public firms' boards of directors is to monitor managerial performance and, as deemed necessary, to hire, fire, and set compensation for these firms' senior executives (Furtado and Karan 1990). Current explanations regarding the hiring, firing and compensation of senior executives draw largely from the upper echelons perspective (e.g., Finkelstein et al. 2009), from power and resource dependency perspectives (e.g., Pfeffer and Salancik 1978), and from labor market and managerial human capital perspectives (e.g., Carpenter and Wade 2002; Castanias and Helfat 2001; Fama 1980). Research on executive compensation, for example, nicely illustrates the blending of these theoretical perspectives in confirming that the managerial talent market values executives possessing the skills and abilities to orchestrate across their respective organizations the exploitation of strategic opportunities and the mitigation of critical problems (Carpenter and Wade 2003; Castanias and Helfat 2001).

Given that firm performance is seen as a key indicator of managerial performance, considerable research has examined the influence of firm performance on both executive compensation and executive turnover. For the most part, the research examining the relationship between firm performance and executive compensation has proved inconclusive, attributed to numerous intruding contingencies (Finkelstein et al. 2009). However, research consistently attributes senior executive turnover to poor firm performance (e.g., Finkelstein et al. 2009; Wagner et al. 1984; Wiesenfeld et al. 2008). That said, the studies examining the influence of poor firm performance on senior executive turnover have operationalized firm performance in broad, nonspecific ways - making it impossible to attribute executive turnover with performance deficiencies regarding specific executive responsibilities (Finkelstein et al. 2009; Wiensenfeld et al. 2008).

A notable exception is the study by Arthaud-Day et al. (2006) that examines the influence of financial restatements on $\mathrm{CEO} / \mathrm{CFO}$ turnover within the post-SOX financial reporting context. When errors are identified in issued financial statements, these in-error financial statements must be corrected, or restated. Building on Wiensenfeld et al.'s (2008) ideas regarding stigmatization processes taken to rectify firms' loss of legitimacy, Arthaud-Day et al. (2006) argue

we propose that financial restatements represent a particularly serious threat to legitimacy, especially with respect to the regulatory and normative environments. Because the executives of a firm are held directly responsible for restatements, we suggest that removing these stigmatized leaders aids the firm's recovery process (p. 1122).

Arthaud-Day et al. then provided evidence that CEOs and CFOs in restatement firms were more likely to suffer turnover than were CEOs and CFOs in non-restatement firms and that restatement events proved significant in explaining executive turnover after accounting for the influence of firm financial performance. ${ }^{4}$ Arthaud-Day et al. conclude that "financial

\footnotetext{
${ }^{4}$ Related research has produced consistent findings: restatements are associated with stock price declines (Hammersley et al. 2008; Palmrose et al. 2004), suggesting legitimacy losses; and, restatements are associated with higher rates of senior executive turnover (Collins et al. 2009; Desai et al. 2006).
} 
restatements have less causal ambiguity, making it easier to pinpoint culpability" (p. 1130).

As described earlier, material weaknesses contribute directly to firms' issuance of financial restatements, with IT material weaknesses being especially damaging to firms' legitimacy as transaction partners are likely to be concerned that identified IT deficiencies will require complex, costly and timeconsuming repairs. Because (1) a firm's senior executives are expected by the firm's board of directors to possess the requisite managerial skills and abilities to maintain the firm's on-going success and (2) effective IT management has become critical to the on-going success of most firms, we propose

\section{Hypothesis 1: Firms reporting greater numbers of IT material weaknesses will experience greater likelihoods of CEO turnover.}

\section{Hypothesis 2: Firms reporting greater numbers of IT material weaknesses will experience greater likelihoods of CFO turnover.}

We now extend Arthaud-Day et al.'s work by developing hypotheses reflecting a finer delineation of the IT management responsibilities for which CEOs and CFOs are likely to be held accountable, thereby removing another layer of causal ambiguity. To accomplish this, however, we first partition firms' IT management responsibilities into three distinct domains.

\section{IT Management Responsibility Domains}

Synthesizing prior thought (Chen et al. 2010; Feeney and Willcocks 1998; Ross and Weill 2002; Sambamurthy and Zmud 2012; Weill 2004), we argue that three primary domains of IT management responsibilities exist: a global domain, a demand-side domain and a supply-side domain. Table 1 characterizes these three responsibility domains.

Global IT management activities focus on positioning, directing, and overseeing enterprise-wide IT policies and IT strategies in order to set the strategic tone for IT investment, to optimally leverage IT investments, and to minimize ITrelated risks (Ross and Weill 2002; Sambamurthy and Zmud 2012; Weill 2004). Here, senior executive engagement is especially important in resolving the interunit tensions that arise from resource prioritizations attributed to demand-side and/or supply-side imbalances - imbalances that can become intractable if not quickly resolved because of the involvedexecutives' power.
Demand-side IT management activities focus on stimulating, prioritizing, and constraining unit-specific demands for ITenabled business solutions and enabling technology services. Typically, these organizational units represent business units, functional line units, or functional staff units; and both strategic and operational issues are addressed when specifying a unit's IT-related requirements, overseeing the provisioning of IT-enabled business solutions, and ensuring that these solutions are aligned with current and planned business strategies. Senior executive engagement is especially important in resolving two issues resulting from intra-unit tensions (Fonstad and Robertson 2006; Ross and Weill 2002; Sambamurthy and Zmud 2015): determining which business needs are to be met through unit-wide business solutions and which are to be met by locally optimized business solutions, and establishing priorities for competing business needs in the face of resource constraints.

Supply-side IT management activities focus on provisioning, operating, and maintaining the (enterprise-wide and unitspecific) IT-enabled business solutions and enabling technology services implemented to support and enable an organization's business strategies and business operations (Chen et al. 2010; Sambamurthy and Zmud 2012). While such activities might be physically executed by internal entities (with either an enterprise-wide or localized purview) or by external entities (e.g., consultancies or service providers), concerns related to security, interconnectivity, interoperability, optimization, and lifetime costs of ownership are moving most firms toward a greater centralization of supplyside IT management (Kettinger et al. 2010; Sambamurthy and Zmud 2012). Senior executive engagement is especially important in resolving two issues related to interunit tensions (Fonstad and Robertson 2006; Sambamurthy and Zmud, 2012): ensuring that to-be-provisioned technology assets conform to enterprise-wide technology standards, architectures, and security polices; and allowing unit-level senior executives confronting demand-side IT management decisions sufficient flexibility to maintain and enhance their units' competitiveness.

\section{Influence of Specific IT Material Weaknesses on CEO/CFO Turnover}

Prior research in the post-SOX context suggests that executives holding specialized financial expertise, such as the CFO, are likely to suffer greater dysfunctional consequences given the presence of identified material weaknesses than are executives in general management roles, such as the CEO (Hoitash et al. 2012; Hsu and Liao 2012; Li et al. 2010; Wang 2010). That said, material weaknesses of a more general nature seem 


\begin{tabular}{|c|c|c|}
\hline Domain & Focus & Illustrative Decisions \\
\hline Global & $\begin{array}{l}\text { Positioning, directing, and over- } \\
\text { seeing enterprise-wide IT policies } \\
\text { and IT strategies so as to set the } \\
\text { strategic tone for IT investment, to } \\
\text { optimally leverage IT investments, } \\
\text { and to minimize IT-related risks. }\end{array}$ & $\begin{array}{l}\text { - What should the dominant strategic role of IT be? } \\
\text { - What should be the overall level of IT investment? } \\
\text { - Which IT-enabled business solutions and which technology } \\
\text { services should be supported through enterprise-wide digital } \\
\text { platforms? } \\
\text { - Should corporate pay a portion of the cost of innovative, unit- } \\
\text { specific, IT-enabled business solutions? } \\
\text { - How should IT-related business risks be assessed, monitored, and } \\
\text { mitigated? }\end{array}$ \\
\hline Demand-Side & $\begin{array}{l}\text { Stimulating, prioritizing and con- } \\
\text { straining unit-specific demands for } \\
\text { IT-enabled business solutions and } \\
\text { for technology services. }\end{array}$ & $\begin{array}{l}\text { - How should IT-enabled business initiatives be prioritized? } \\
\text { - How should business cases for digital innovations, for IT-enabled } \\
\text { business initiatives, and for technology services be argued? } \\
\text { - Which business processes and enabling technology services are } \\
\text { sufficiently unique to warrant not having to conform to available, } \\
\text { enterprise-wide digital platforms? }\end{array}$ \\
\hline Supply-Side & $\begin{array}{l}\text { Provisioning, operating, and main- } \\
\text { taining (enterprise-wide and unit- } \\
\text { specific) IT-enabled business } \\
\text { solutions and enabling technology } \\
\text { services implemented in support } \\
\text { of an organization's business stra- } \\
\text { tegies and business operations. }\end{array}$ & $\begin{array}{l}\text { - Which technology services should be provisioned through } \\
\text { standardized, enterprise-wide platforms? } \\
\text { - How should technology standards be established and managed? } \\
\text { - Which technology services should and should not be outsourced? } \\
\text { - How should the organization's technology professionals be hired, } \\
\text { developed, and managed? } \\
\text { - How should technology risks be assessed, monitored, and } \\
\text { mitigated? }\end{array}$ \\
\hline
\end{tabular}

to be beyond the CFO's direct responsibility (Hoitash et al. 2012); and, when CEO and CFO compensation changes are examined together, Hsu and Liao (2012) find that compensation is reduced more by general, or company-level, material weaknesses relative to account-specific material weaknesses. ${ }^{5}$ These observations strongly suggest that boards of directors penalize CEOs and CFOs differently for reported material weaknesses, based on the natures of the disclosed material weaknesses and on the distinct fiduciary responsibilities of CEOs and CFOs. We extrapolate these findings to argue that boards of directors are likely to differentially penalize CEOs and CFOs given the natures of disclosed IT material weaknesses.

What are the IT management responsibilities for which boards of directors are likely to hold CEOs accountable for poor performance? The most distinctive responsibility of the CEO's general management role is that of ensuring an organization's strategic flexibility (Nadkami and Hermann 2010) - that is, an organization's capability to precipitate strategic change. Information systems scholars (e.g., Armstrong and Sambamurthy 1999; Kettinger et al. 2010;

\footnotetext{
${ }^{5} \mathrm{Hsu}$ and Liao do not present or discuss results for CEOs and CFOs separately.
}

Pralahad and Krishnan 2002; Ross 2003; Ross et al. 2006; Tallon and Pinsonneault 2011) have argued compellingly that an organization's strategic flexibility is inextricably linked to the existence of a scalable, adaptable enterprise architecture enabling: secured-access to shared data repositories and to robust portfolios of rationalized information systems and their enabling technology services; the seamless integration of these information systems; and, an ease of modifying existing information systems and of implementing new information systems. In the absence of well-tuned enterprise architectures, organizations' collections of installed IT-enabled business solutions become

so complex that any change required individually rewiring systems to all the other systems they connect to. Developing and testing new capabilities in such a complex environment is time consuming and every change becomes a risky, expensive adventure (Ross et al. 2006, p. 11).

Ensuring organizations' strategic flexibility through welltuned enterprise architectures captures a core aspect of global IT management responsibilities, given that a primary aim of enterprise architectures is to more-fully leverage an organization's IT investments and to lower strategic risks (Ross et al. 2006). As the aims of enterprise architectures are often at 
odds with the demand-side strategies of unit-level senior executives (Shpilberg et al. 2007), the CEO is typically the only senior executive holding sufficient political and financial capital to drive significant, global organizational and technological change (Brown and Vessey 2003; Hirschheim et al. 2010; Kohli and Johnson 2011; Leonard-Barton and Deschamps 1988; Smith et al. 2010).

We thus expect that boards of directors will hold an organization's CEO accountable for global IT management responsibilities and will penalize the CEO for poor performance outcomes regarding these global responsibilities. Mapping this argument to the post-SOX financial reporting context,

\section{Hypothesis 3: Firms reporting a greater number of global IT material weaknesses will experience greater likelihoods of CEO turnover.}

What are the IT management responsibilities for which boards of directors are likely to hold CFOs accountable for poor performance? Perhaps the most important functional manager role is that of directing and overseeing the development of a functional unit's business strategy along with that of ensuring integrity of the business operations put in place to achieve this strategy. Indeed, this notion lies at the heart of the arguments raised for line (or functional) executives to "take the lead" in IT management (Martin et al. 1995; Rockart 1988). As IT deployment becomes increasingly pervasive, a dominating functional-manager responsibility involves directing and arbitrating the IT-enabled business solutions and the enabling technology services on which functional strategies and operations are dependent. Such an obligation is reflective of demand-side IT management responsibilities.

We thus expect that boards of directors will hold an organization's CFO accountable for demand-side IT management responsibilities and will penalize the $\mathrm{CFO}$ for poor performance outcomes regarding these demand-side responsibilities. Mapping this argument to the post-SOX financial reporting context,

\section{Hypothesis 4. Firms reporting a greater number of demand-side IT material weaknesses will expe- rience greater likelihoods of CFO turnover.}

Conspicuously missing from our hypotheses is a consideration of supply-side IT management responsibilities. Serving as the senior executive responsible for a firm's IT function, we acknowledge that the CIO has been (Chen et al. 2010), and is expected to continue being, accountable for firms' supply-side IT management responsibilities.

\section{Research Methods}

The SOX financial reporting context is ideally suited, for two reasons, for our research purposes. First, the potential for negative consequences to arise from CEOs and CFOs being held accountable for serious IT deficiencies is explicitly recognized, unlike most other IT management activity domains where the threat of negative consequences from serious IT deficiencies is, at best, implicit. Second, financial reporting is critically important for all publically owned firms, unlike many other work activities whose importance varies as a function of firms' enacted business models, organizational fields, and histories. We collected the data used to assess our research hypotheses from Audit Analytics (e.g., SOX 404 reports), Annual Compustat (financial statement variables), SEC financial reports (e.g., DEF 14-A; 10-K), Execucomp (CEO and CFO variables), and a variety of sources including the Million Dollar Database, Lexis-Nexis, ZoomInfo, and Google Searches.

Using data from Audit Analytics, we examined each firm's reported material weaknesses and classified each as either an IT material weakness or a non-IT material weakness. To obtain our sample of IT material weakness firms, we first identified firm-year observations reporting IT-related weaknesses in 10-K, SOX 404 audited management disclosures with fiscal year-ends from November 2004 through December 2007. We then required that firms have subsequent proxy filings (DEF 14-A) to the SEC, so we could determine changes in CEO and CFO positions. Second, some firms have IT weaknesses in consecutive years. If we observed turnover to have occurred for both the CEO and CFO in the first year of an IT material weakness, we did not include subsequent firm-year observations for that firm. ${ }^{6}$ After this process, we obtained 278 IT material weakness firm-year observations.

After having identified our sample of IT material weakness firms, we then selected a second group of non-IT material weakness firms matched on industry, profitability (return on assets), and size (market capitalization) that reported material weaknesses but with none of the reported material weaknesses being an IT material weakness. ${ }^{7}$ For each firm in our combined data set, we searched SEC proxy statements to identify

\footnotetext{
${ }^{6}$ If we observe turnover for only one of a firm's $\mathrm{CxO}$ (either the $\mathrm{CEO}$ or $\mathrm{CFO}$ ) for a given year's SOX 404 report, we do not include subsequent firmyear observations for that particular $\mathrm{C} x \mathrm{O}$.

${ }^{7}$ All but two of the firms in the IT material weakness group report both IT and non-IT material weaknesses, thus precluding analyses contrasting firms with only IT material weaknesses and firms with only non-IT material weaknesses.
} 
CEO and CFO turnover rates. Our complete sample consists of 278 firm-year observations for both the IT material weakness group and the matched non-IT material weakness group. In assessing our first two research hypotheses, our analysis strategy involves examining, via probit regression analysis, whether or not the presence of IT material weaknesses results in a higher likelihood of $\mathrm{C} x \mathrm{O}$ turnover while controlling for non-IT material weaknesses, whether the CIO reports to the CEO or the CFO (proxied by estimating the likelihood of the CIO reporting to the CEO), the extent to which a firm's CIO is held responsible for the identified IT material weaknesses (proxied by estimating the likelihood of CIO turnover), and other variables previously found to influence $\mathrm{CxO}$ turnover. In assessing our last two research hypotheses, our analysis strategy involves identifying (again via probit regression analysis) specific IT material weaknesses that result in a higher likelihood of $\mathrm{C} x \mathrm{O}$ turnover, accounting for the same control variables used in assessing the first two hypotheses.

The dependent variables are $\mathrm{C} x \mathrm{O}$ turnover, where $x$ equates to "E" or to " $\mathrm{F}$ " to indicate $\mathrm{CEO}$ and $\mathrm{CFO}$, respectively. $\mathrm{C} x \mathrm{O}$ turnover is defined as having a value of one if the incumbent left the $\mathrm{C} x \mathrm{O}$ position in the year after $(\mathrm{t}+1)$ or two years after $(\mathrm{t}+2)$ the year for which a SOX 404 material weakness was identified or a value of zero otherwise. ${ }^{8}$ Thus, for example, $\mathrm{C} x \mathrm{O}$ departures associated with fiscal year 2004 SOX 404 reports included departures in 2005 or 2006.

Our primary independent variable is Number of IT Weaknesses, that is, the number of material weaknesses identified in a given SOX 404 report that we characterize as IT deficiencies. We also use Number of Non-IT Weaknesses, that is, the number of material weaknesses identified in a given SOX 404 report that we do not characterize as IT deficiencies, as a control variable. ${ }^{9}$ While no standards exist regarding the descriptions to be given to IT and non-IT material weaknesses in SOX 404 reports, these reports do describe the nature of each identified material weakness. Most commonly, a specific material weakness is described within a separate paragraph (or bullet); however, in some cases, multiple paragraphs might be used to describe a single material weakness, and in other cases all material weaknesses might be described in a single paragraph. Such nonstandard reporting practices present challenges when discriminating between IT and nonIT material weaknesses and when counting the number of IT and non-IT material weaknesses. In our coding process (described below), we classify a material weakness explicitly

\footnotetext{
${ }^{8} \mathrm{We}$ do not set $\mathrm{C} x \mathrm{O}$ turnover equal to one if a departing $\mathrm{C} x \mathrm{O}$ is above 65 years old.

${ }^{9}$ In our probit regressions, we use the natural log of Number of IT Weaknesses and Number of Non-IT Weaknesses.
}

described as at least one IT deficiency as an IT material weakness; otherwise, the material weakness is classified as a non-IT material weakness. Audit Analytics does provide a total count of all material weaknesses in a given SOX 404 report, which we first verified. Using this verified number as the ceiling for the number of material weaknesses identified in a firm's SOX 404 report, we were able to confidently derive counts of the IT and non-IT material weaknesses. Thus, for each firm, the sum of the number of IT material weaknesses (Number of IT Weaknesses) and the number of non-IT material weaknesses (Number of Non-IT Weaknesses) equals the total number of verified material weaknesses provided by Audit Analytics.

As the reported IT material weaknesses referenced a variety of IT deficiencies, we developed a coding scheme to categorize these IT material weaknesses. Most firms use COSO's 1992 Internal Control-Integrated Framework to evaluate internal controls (Klamm and Watson 2009), supplemented by the COBIT control framework (ITGI 2007) in examining IT-related aspects. Accordingly, one of the authors used the COBIT framework as a lens to enumerate the specific IT deficiencies described as material weaknesses in SOX 404 reports. Next, a practitioner forum was engaged to discuss the salience of these IT material weaknesses within the SOX regulatory/audit context. All four coauthors participated in a conference call with nine practitioners (CIOs, chief technology officers, or senior IT audit specialists) representing either Fortune 500 companies or major IT audit consultancies. Following this conference call, the coauthor who had enumerated the initial set of IT material weaknesses met with the practitioner forum's lead participant (a CTO active in IT audit research) to apply the spirit of the conference call in revisiting the enumerated IT deficiencies, producing a list of 35 IT material weaknesses. Using this list, this co-author with the assistance of a second coauthor read each firm's SOX 404 report to make sure that the IT material weaknesses were properly coded. Then, three of the coauthors engaged in a series of meetings to reach a consensus on a final set of IT material weakness categories, combining certain IT material weaknesses to ensure that each was unique and eliminating certain IT material weaknesses to ensure that each clearly reflected IT concerns rather than accounting concerns. After applying these two criteria, the number of distinct IT material weaknesses was trimmed to 16 . Li et al. (2012) have empirically demonstrated the meaningfulness of such an approach to coding SOX 404 reported IT material weaknesses.

Appendix B describes an exploratory factor analysis subsequently carried out to yield the parsimonious IT material weakness factor structure depicted in Table 2. (Appendix B also describes how the initial set of 16 IT material weaknesses 


\begin{tabular}{|l|l|l|}
\hline \multicolumn{1}{|c|}{$\begin{array}{c}\text { Table 2. Derived IT Material Weakness Categories Factor Structure } \\
\text { [IT Management } \\
\text { Responsibility Domain] }\end{array}$} & \multicolumn{1}{|c|}{$\begin{array}{c}\text { IT Material } \\
\text { Weaknesses }\end{array}$} & \multicolumn{1}{c|}{ Description } \\
\hline $\begin{array}{l}\text { IT Control Oversight-Internal } \\
\text { [Demand-Side] }\end{array}$ & $\begin{array}{l}\text { Segregation of Duties } \\
\text { Backup/Recovery/Security } \\
\text { Access Control } \\
\text { IT Management Oversight }\end{array}$ & $\begin{array}{l}\text { Ensuring that proper internal controls have been established } \\
\text { for financial information systems and associated technology } \\
\text { services. }\end{array}$ \\
\hline $\begin{array}{l}\text { IT Capability } \\
\text { [Demand-Side] } \\
\text { [Supply-Side] }\end{array}$ & $\begin{array}{l}\text { IT Skillbase } \\
\text { Business Analysis } \\
\text { Infrastructure/Operations } \\
\text { knowledge, work practices, and processes, etc.) exist to } \\
\text { analyze, design, build, implement, operate, and maintain } \\
\text { financial information systems and associated technology } \\
\text { services. }\end{array}$ \\
\hline $\begin{array}{l}\text { Software Development } \\
\text { [Demand-Side] } \\
\text { [Supply-Side] }\end{array}$ & $\begin{array}{l}\text { Software Development } \\
\text { Software Implementation } \\
\text { Data Integrity }\end{array}$ & $\begin{array}{l}\text { Ensuring the effective design, development, testing, } \\
\text { installation, and maintenance of financial information } \\
\text { systems and associated data. }\end{array}$ \\
\hline $\begin{array}{l}\text { IT Architecture } \\
\text { [Global] }\end{array}$ & $\begin{array}{l}\text { Non-Integrated Application } \\
\text { Systems } \\
\text { Too Complex Systems }\end{array}$ & $\begin{array}{l}\text { Ensuring that enterprise and technology architectures exist } \\
\text { to rationalize and integrate an organization's portfolio of } \\
\text { financial information systems. }\end{array}$ \\
\hline $\begin{array}{l}\text { IT Control Oversight-External } \\
\text { [Supply-Side] }\end{array}$ & $\begin{array}{l}\text { Spreadsheet Integrity } \\
\text { Outsourcing }\end{array}$ & $\begin{array}{l}\text { Ensuring that proper controls have been established for the } \\
\text { financial information systems and associated technology } \\
\text { services developed and/or operated by entities other than an } \\
\text { organization's internal IT function. }\end{array}$ \\
\hline
\end{tabular}

aThese IT material weaknesses reference deficiencies explicitly described as being IT-related. For example, a "Segregation of Duties" IT material weakness would refer to a single individual carrying out multiple IT-related tasks, each of which should have been segregated across multiple individuals.

was further trimmed to the 14 listed in the second column of Table 2.) In carrying out this factor analysis, we used as data items the count of the number of times each IT material weakness was reported in a firm's SOX 404 report for a given year. Appendix B also provides the justification (see the fourth column of Table B4) for mapping these IT material weakness categories to the three categories of IT management responsibilities defined earlier. Specifically, IT Architecture is identified as a global responsibility, IT Control OversightInternal is identified as a demand-side responsibility, IT Control Oversight-External is identified as a supply-side responsibility, and IT Capability and Software Development are identified as having aspects of both demand-side and supply-side responsibilities.

While we are confident in our ability to recognize the existence of a specific IT material weakness, we are less confident in our ability to count, for a firm, the total number of distinct occurrences of a specific IT material weakness. As a consequence, we operationalize the IT material weakness categories both as indicator variables and as count variables, and we produce regression results for both operationalizations. ${ }^{10}$

\footnotetext{
${ }^{10}$ When operationalizing IT material weakness categories as count variables in our probit regressions, we use the natural log of the counts.
}

Seeking to be as conservative as possible, we apply regression results for the indicator-operationalization when examining Hypotheses 3 and 4 . The indicator variables denote whether or not a firm disclosed at least one of the IT material weaknesses in a specific IT material weakness category.

Our primary control variables are Number of Non-IT Weaknesses, CIO Reporting Probability, and CIO Turnover Probability. Earlier in this section we described our measure of Number of Non-IT Weaknesses. Given the results provided by Arthaud-Day (2006) regarding financial reporting restatements, we expect this variable to significantly predict $\mathrm{C} x \mathrm{O}$ turnover.

We also control for whether the CIO reports to the CEO or CFO. We expect CEO (CFO) turnover to be higher (lower) when the CIO reports directly to the CEO. Data limitations prohibit us from documenting CIO reporting structure for the majority of our sample firms. Therefore, we construct a $C I O$ Reporting Probability variable following the CIO reporting prediction model developed by Banker et al. (2011). Using the 2006 sample period, Banker et al. find that operating income over sales is positively associated with $\mathrm{CIO}$ reporting to the $\mathrm{CEO}$ (rather than reporting to the $\mathrm{CFO}$ ) and that sales over assets is negatively associated with the $\mathrm{CIO}$ reporting to the $\mathrm{CEO}$ (rather than reporting to the $\mathrm{CFO}$ ). Thus, our $\mathrm{CIO}$ 
Reporting Probability variable is constructed by taking the sum of (10.2511* Operating Income over Sales) and (-1.6118 * Sales over Assets). ${ }^{11}$

Because of data limitations, we are unable to document CIO turnover for the majority of our sample firms. Therefore, we construct a CIO Turnover Probability variable. In Appendix $\mathrm{C}$, we present the results of two probit regression models predicting CIO turnover using a limited set of our sample firms for which we were able to locate the needed CIO data. In Model 1 (Model 2) of Appendix C, we operationalize the IT material weakness categories as indicator (count) variables. We find that the coefficients for IT Control OversightExternal, Size, Profit, and Board Independence to be significant (at a 0.1 probability level) predictors of CIO turnover. From Model 1 of Appendix C, CIO Turnover Probability is set equal to zero (one) if the sum of $\left(0.569^{*}\right.$ IT Control Oversight-External $)+(0.211 *$ Size $)+(-0.016 *$ Profit $)+$ $(1.405 *$ Board Independence) is below (above) the sample median. From Model 2 of Appendix C, CIO Turnover Probability is set equal to zero (one) if the sum of $\left(0.748^{*}\right.$ IT Control Oversight-External $)+(0.206 *$ Size $)+(-0.016 *$ Profit $)+(1.415 *$ Board Independence) is below (above) the sample median. ${ }^{12}$

Informed by prior work, we account for additional alternative explanations of executive turnover by including salient control variables. To control for firm size (Size), we use the natural log of the firm's market capitalization (in \$million). Prior research has consistently observed that poor performance increases the likelihood of executive turnover (e.g., Boeker 1992; Murphy and Zimmerman 1993; Puffer and Weintrop 1991; Warner et al. 1988; Weisbach 1988). Thus, we control for Profit, which is measured as the firm's return on assets (ROA) ratio. To further control for the firm's financial health, we include Growth, measured as total sales in the current year divided by sales in the prior year, and Leverage, measured as total liabilities divided by total assets. We control for financial reporting restatements with the variable Restatement, which is an indicator variable set to one if the firm reported a restatement during the year of SOX 404 material weakness, zero otherwise. In addition, we control for whether the firm received a Going Concern opinion (i.e., an assessment of a company's inability to continue functioning

\footnotetext{
${ }^{11}$ Banker et al. argue that "Operating Income over Sales" is a proxy for a differentiation positioning strategy and "Sales over Assets" is a proxy for a cost leadership positioning strategy.

${ }^{12}$ Due to multicollinearity problems, we cannot include the raw values of computed CIO turnover probability. In the subsequent CEO and CFO probit regressions, we control for CIO Turnover Probability derived from Model 1 (Model 2) of Appendix C when including IT material weakness categories operationalized as indicator (count) variables.
}

as a business entity) from their auditors through the use of an indicator variable set to one if the firm did receive such an opinion, zero otherwise.

Corporate governance also influences the likelihood of management turnover. Prior research (e.g., Fama and Jensen 1983; Jensen 1993; Weisbach 1988) suggests that when corporate governance is weak, boards cannot effectively perform their monitoring functions including those of evaluating and replacing poorly performing executives. Yermack (1996) provides evidence suggesting that smaller board sizes are associated with good governance. In addition, Weisbach (1988) finds that the firm's ability to replace CEOs for poor performance is greater with a higher proportion of outside directors. Therefore, we include as control variables the number of directors that sit on the board (Board Size) and Board Independence, measured as the number of outside directors divided by the total number of directors. We also include the variable Audit Committee Effective to control for the strength of the audit committee. This variable is defined (inversely) as one if a firm's SOX 404 report mentioned significant deficiencies relating to the firm's audit committee, zero otherwise. To control for the monitoring of institutional owners, we include Institutional Ownership, defined as percentage of shares owned by institutional shareholders.

$\mathrm{C} x \mathrm{O}$ power may also significantly affect the probability of executive turnover (Boeker 1992; Shen and Cannella 2002; Zhang and Rajagopalan 2004). Boeker (1992) and Jensen (1993) argue that the board's ability to discipline the $\mathrm{CxO}$ of a poorly performing firm is curtailed when the $\mathrm{C} x \mathrm{O}$ has acquired substantial power. Accordingly, we employ two measures of CEO power: CEO pay slice (i.e., the CEO's pay as a proportion of that received by top five corporate officers) (Bebchuk et al. 2011), and CEO as Chairman (i.e., the CEO also serves as board chairman). Likewise, we control for CFO pay slice when examining $\mathrm{CFO}$ turnover. In addition, the likelihood of turnover for subordinate executives may increase, through a scapegoating phenomenon (Boeker 1992), when their superior is powerful and retains their position by scapegoating a subordinate. Thus, we control for CEO power in examining CFO turnover.

We also control for executive tenure, age, and IT expertise in these $\mathrm{CEO}$ and $\mathrm{CFO}$ turnover analyses. $\mathrm{CxO}$ tenure is measured as the executive's tenure in the year of the SOX 404 report, while $\mathrm{CxO}$ age is measured as the executive's age in the year of the SOX 404 report. CxO IT Expert is an indicator variable set to one if the executive has expertise in IT, and zero otherwise. ${ }^{13}$ Finally, we include three year-indicator

\footnotetext{
${ }^{13} \mathrm{We}$ ascertain if an executive possesses IT expertise by reading his or her biography in the firm's SEC filings (i.e., form DEF 14A, 10-K). An executive possesses IT expertise if he/she has prior experience as a CIO, or other
} 
variables to control for time-specific effects (for brevity, the coefficients for the year-indicator variables are not tabulated in the tables) and a control variable, Prior CxO Turnover, ${ }^{14}$ defined for the CEO analysis as one if a firm had already experienced an instance of CFO turnover subsequent to the reporting of IT material weaknesses and zero otherwise, and defined for the CFO analysis as one if a firm had already experienced an instance of CEO turnover subsequent to the reporting of IT material weaknesses and zero otherwise. ${ }^{15}$

\section{Research Results}

Descriptive statistics and univariate tests are first described to provide a sense of the data as well as naïve (i.e., univariate) observations regarding the influence of IT material weaknesses on $\mathrm{C} x \mathrm{O}$ turnover. Then, we report the results of probit regression analyses examining the influence of IT material weaknesses on $\mathrm{CxO}$ turnover, accounting for the presence of non-IT material weaknesses, of CIO reporting/ turnover probabilities, and of other variables found in prior research to be influential in explaining $\mathrm{CxO}$ turnover.

Table 3 reports descriptive statistics as well as the results of mean-difference tests between the IT material weakness firms and the non-IT material weaknesses firms. The size and profitability variables for the two groups of firms are not statistically different, suggesting that our matching procedure was successful. The finding that restatements are significantly higher with IT material weakness firms relative to nonIT material weakness firms suggests that the IT material weaknesses identified in SOX 404 reports are associated with serious financial reporting problems, adding further credence to the foundational role served by IT in financial statement production. Most important for our research purposes, IT material weakness firms have greater $(p$-value $<0.05)$ instances of CEO (33.3\%) and CFO (47.9\%) turnover compared to non-IT weakness firms $(\mathrm{CEO}=23.4 \%, \mathrm{CFO}=$

IT management positions such as vice president of technology, vice president of information systems, etc., and/or has prior work experience in an information technology firm (e.g., Dell, IBM, Microsoft, software companies, etc.).

\footnotetext{
${ }^{14}$ For example, Company ABC had IT weaknesses in 2004 and 2005. In 2004, there was CEO turnover but NOT CFO turnover. Thus, for 2005, we did not track CEO turnover but DID track CFO turnover. In other words, Company $\mathrm{ABC}$ for 2005 is still included in the sample for CFO turnover purposes. Thus, for the 2005 observation in the CFO analysis, the variable Prior CxO Turnover $=1$.

${ }^{15}$ To reduce the influence of outliers, we winsorize the variables CIO reporting probability, profit, growth, leverage, and institutional ownership at the $1^{\text {st }}$ and $99^{\text {th }}$ percentile. For missing values in our control variables, we replace missing values with the sample mean.
}

$38.2 \%$ ). These naïve observations are consistent with Hypotheses 1 and 2.

The correlation matrix is provided in Appendix D. Tests for multicollinearity problems within our probit regression analyses indicated that no such concerns existed. Tables 4 and 5 provide results of the probit regression models examining the extent to which IT material weaknesses influence the probability of, respectively, CEO and CFO turnover, controlling for the effects of other variables. ${ }^{16}$ In Tables 4 and 5, coefficients for variables were standardized. The sample used in these regression analyses combines the IT material weakness firms and the non-IT material weakness firms. In these results, Model 1 and Model 2 include the control variables only. Model 3 adds the Number of IT Weaknesses variable, and these results inform the testing of Hypotheses 1 and 2. In Model 4 and Model 5, the Number of IT Weaknesses variable from Model 3 is removed and replaced with the five IT material weakness categories in assessing Hypotheses 3 and 4 (Model 4 uses indicator variables while Model 5 uses count variables).

Table 4 provides the results for CEO turnover. In Model 3, Number of IT Weaknesses is significant in predicting CEO turnover $(p$-value $<0.01)$. Thus, the results suggest that IT weakness firms are more likely to have CEO turnover compared to non-IT weakness firms and that the number of IT weaknesses is positively associated with the probability of CEO turnover. These results provide strong support for Hypothesis 1. With regard to the influence of specific IT material weakness categories on CEO turnover, Model 4 (using indicator variables) shows that IT Architecture ( $p$-value $<0.01)$ and IT Control Oversight-External ( $p$-value $<0.05)$ are significant predictors - providing moderately strong support for Hypotheses 3. Model 5 (using count variables) as well shows IT Architecture ( $p$-value $<0.01)$ and IT Control Oversight-External ( $p$-value $<0.05$ ) to be significant predictors-again providing moderately strong support for Hypothesis 3.

Table 5 provides the results for $\mathrm{CFO}$ turnover. In Model 3, Number of IT Weaknesses is significant in predicting CFO turnover $(p$-value $<0.05)$. Thus, the results suggest that IT weakness firms have a greater likelihood of having CFO turnover compared to non-IT weakness firms and the number of IT weaknesses is positively associated with the likelihood

\footnotetext{
${ }^{16}$ We contemplated the possibility that SOX 404 reports would systematically vary depending on the external auditor. We tested this by including an additional dummy variable that equals one for a Big 4 firm and zero otherwise (as both a main effect and as an interaction with IT and non-IT material weakness). We did not find that the type of external auditor to be a significant determinant as either a main effect or in an interaction with IT and non-IT material weaknesses.
} 


\begin{tabular}{|c|c|c|c|c|c|}
\hline \multirow[b]{2}{*}{ Variables } & \multicolumn{2}{|c|}{ IT Weakness Firms (a) } & \multicolumn{2}{|c|}{$\begin{array}{c}\text { Non - IT Weakness Firms } \\
\text { (b) }\end{array}$} & \multirow{2}{*}{$\begin{array}{c}\begin{array}{c}\text { p-value } \\
\text { Difference }\end{array} \\
\text { (a) - (b) }\end{array}$} \\
\hline & Mean & Median & Mean & Median & \\
\hline \multicolumn{6}{|l|}{ Panel A. IT Weakness Variables } \\
\hline Number of IT Weaknesses & 1.719 & 1.000 & & & \\
\hline IT Control Oversight - Internal & 0.633 & 1.000 & & & \\
\hline IT Capability & 0.252 & 0.000 & & & \\
\hline Software Development & 0.502 & 1.000 & & & \\
\hline IT Architecture & 0.112 & 0.000 & & & \\
\hline IT Control Oversight - External & 0.309 & 0.000 & & & \\
\hline \multicolumn{6}{|l|}{ Panel B. CEO and CFO Turnover } \\
\hline CEO Turnover & 0.333 & 0.000 & 0.234 & 0.000 & ** \\
\hline CFO Turnover & 0.479 & 0.000 & 0.382 & 0.000 & ** \\
\hline \multicolumn{6}{|l|}{ Panel C. Control Variables } \\
\hline ClO Reporting Probability & -4.209 & -1.833 & -4.358 & -1.468 & \\
\hline $\mathrm{ClO}$ Turnover Probability & 2.666 & 2.667 & 2.470 & 2.436 & $* * *$ \\
\hline CEO IT Expert & 0.267 & 0.000 & 0.220 & 0.000 & \\
\hline CFO IT Expert & 0.274 & 0.000 & 0.263 & 0.000 & \\
\hline Number of Non-IT Weaknesses & 2.518 & 1.000 & 1.928 & 1.000 & *** \\
\hline Size & 5.893 & 5.726 & 5.966 & 5.831 & \\
\hline Profit (in \%) & -8.344 & -0.592 & -6.493 & -0.142 & \\
\hline Restatement & 0.353 & 0.000 & 0.248 & 0.000 & $* * *$ \\
\hline Going Concern & 0.053 & 0.000 & 0.046 & 0.000 & \\
\hline Growth & 1.245 & 1.122 & 1.186 & 1.079 & \\
\hline Leverage & 0.599 & 0.588 & 0.523 & 0.504 & $* \star \star *$ \\
\hline Institutional Ownership & 0.592 & 0.602 & 0.613 & 0.602 & \\
\hline Audit Committee Effective & 0.039 & 0.00 & 0.007 & 0.000 & ** \\
\hline CEO as Chairman & 0.536 & 1.000 & 0.486 & 0.000 & \\
\hline Board Size & 7.764 & 8.000 & 7.888 & 8.000 & \\
\hline Board Independence & 0.792 & 0.818 & 0.788 & 0.833 & \\
\hline CEO Pay Slice & 0.307 & 0.304 & 0.301 & 0.303 & \\
\hline CFO Pay Slice & 0.175 & 0.177 & 0.177 & 0.174 & \\
\hline CEO Age & 54.263 & 54.000 & 54.369 & 54.000 & \\
\hline CFO Age & 49.906 & 50.000 & 49.184 & 49.000 & \\
\hline CEO Tenure & 7.165 & 4.000 & 7.061 & 5.000 & \\
\hline CFO Tenure & 3.579 & 2.000 & 3.872 & 3.000 & \\
\hline Prior CxO Turnover & 0.086 & 0.000 & 0.000 & 0.000 & $* * *$ \\
\hline
\end{tabular}

Note: ${ }^{* * *} p<0.01,{ }^{* *} p<0.05,{ }^{*} p<0.10$ 


\begin{tabular}{|c|c|c|c|c|c|}
\hline & Model 1 & Model 2 & Model 3 & Model 4 & Model 5 \\
\hline Number of IT Weaknesses & & & $0.168^{* * *}$ & & \\
\hline IT Control Oversight-Internal & & & & -0.006 & 0.014 \\
\hline IT Capability & & & & 0.024 & 0.016 \\
\hline Software Development & & & & 0.014 & 0.017 \\
\hline IT Architecture & & & & $0.166^{\star * *}$ & $0.157^{* * *}$ \\
\hline IT Control Oversight-External & & & & $0.133^{* *}$ & $0.132^{\star *}$ \\
\hline CIO Reporting Probability & & 0.013 & 0.011 & 0.001 & 0.004 \\
\hline CIO Turnover Probability & & 0.075 & 0.022 & -0.040 & -0.019 \\
\hline CEO IT Expert & 0.034 & 0.028 & 0.029 & 0.027 & 0.028 \\
\hline Number of Non-IT Weaknesses & $0.096^{*}$ & $0.094^{*}$ & 0.082 & $0.094^{*}$ & 0.085 \\
\hline Size & -0.109 & $-0.148^{*}$ & -0.114 & -0.098 & -0.106 \\
\hline Profit & $-0.207^{* * *}$ & $-0.176^{* *}$ & $-0.199^{* * *}$ & $-0.231^{* * *}$ & $-0.222^{* * *}$ \\
\hline Restatement & -0.003 & -0.008 & -0.025 & -0.031 & -0.027 \\
\hline Going Concern & -0.016 & -0.017 & -0.014 & -0.044 & -0.007 \\
\hline Growth & 0.056 & 0.052 & 0.051 & 0.056 & 0.056 \\
\hline Leverage & -0.012 & -0.021 & -0.035 & -0.025 & -0.027 \\
\hline Institutional Ownership & $0.137^{* *}$ & $0.131^{* *}$ & $0.138^{* *}$ & $0.147^{* *}$ & $0.144^{* *}$ \\
\hline Audit Committee Effective & 0.015 & 0.016 & -0.009 & 0.009 & 0.004 \\
\hline CEO as Chairman & -0.024 & -0.023 & -0.038 & -0.039 & -0.040 \\
\hline Board Size & 0.083 & 0.088 & 0.083 & 0.073 & 0.076 \\
\hline Board Independence & $0.125^{\star *}$ & 0.098 & $0.116^{*}$ & $0.138^{* *}$ & $0.129^{*}$ \\
\hline CEO Pay Slice & 0.063 & 0.063 & 0.061 & 0.058 & 0.061 \\
\hline CEO Age & $-0.113^{*}$ & $-0.113^{*}$ & -0.097 & $-0.123^{\star *}$ & $-0.123^{* *}$ \\
\hline CEO Tenure & $-0.139^{*}$ & $-0.139^{*}$ & $-0.136^{*}$ & $-0.134^{*}$ & $-0.133^{*}$ \\
\hline Prior CXO Turnover & -0.057 & -0.062 & -0.088 & -0.074 & -0.078 \\
\hline Intercept & $-1.282^{*}$ & -1.092 & $-1.442^{*}$ & $-1.296^{*}$ & $-1.267^{*}$ \\
\hline Year Indicators & Yes & Yes & Yes & Yes & Yes \\
\hline Number of observations & 546 & 546 & 546 & 546 & 546 \\
\hline$p$-value for Wald $\chi^{2}$ & $<0.01$ & $<0.01$ & $<0.01$ & $<0.01$ & $<0.01$ \\
\hline Area Under ROC Curve & 0.685 & 0.686 & 0.703 & 0.714 & 0.717 \\
\hline
\end{tabular}

Note: ${ }^{* * *} p<0.01,{ }^{* *} p<0.05,{ }^{*} p<0.10$ 


\begin{tabular}{|c|c|c|c|c|c|}
\hline & Model 1 & Model 2 & Model 3 & Model 4 & Model 5 \\
\hline Number of IT Weaknesses & & & $0.145^{\star \star}$ & & \\
\hline IT Control Oversight-Internal & & & & $0.204^{\star \star \star}$ & $0.203^{\star * \star}$ \\
\hline IT Capability & & & & 0.002 & 0.009 \\
\hline Software Development & & & & 0.047 & 0.040 \\
\hline IT Architecture & & & & -0.055 & -0.052 \\
\hline IT Control Oversight-External & & & & -0.058 & -0.072 \\
\hline CIO Reporting Probability & & -0.007 & -0.013 & -0.012 & -0.007 \\
\hline $\mathrm{ClO}$ Turnover Probability & & $-0.218^{\star * *}$ & $-0.264^{\star \star \star}$ & $-0.221^{* *}$ & $-0.185^{\star \star}$ \\
\hline CFO IT Expert & 0.097 & 0.106 & 0.102 & 0.102 & 0.097 \\
\hline Number of Non-IT Weaknesses & $0.171^{* \star *}$ & $0.174^{* \star *}$ & $0.164^{\star \star \star}$ & $0.152^{* * *}$ & $0.145^{* \star *}$ \\
\hline Size & 0.101 & $0.215^{\star * \star}$ & $0.244^{\star \star \star}$ & $0.228^{* * *}$ & $0.201^{* *}$ \\
\hline Profit & $-0.134^{\star \star}$ & $-0.238^{\star \star *}$ & $-0.257^{\star * *}$ & $-0.235^{\star * *}$ & $-0.215^{\star \star}$ \\
\hline Restatement & $0.118^{* \star}$ & $0.137^{* *}$ & $0.123^{* *}$ & $0.137^{* *}$ & $0.135^{* *}$ \\
\hline Going Concern & 0.016 & 0.018 & 0.022 & 0.030 & 0.030 \\
\hline Growth & 0.027 & 0.042 & 0.039 & 0.033 & 0.035 \\
\hline Leverage & $-0.096^{*}$ & -0.069 & -0.079 & -0.080 & -0.081 \\
\hline Institutional Ownership & -0.022 & -0.010 & -0.003 & 0.003 & -0.005 \\
\hline Audit Committee Effective & 0.036 & 0.031 & 0.011 & -0.001 & 0.009 \\
\hline CEO as Chairman & -0.075 & -0.077 & -0.080 & -0.074 & -0.076 \\
\hline Board Size & 0.034 & 0.014 & 0.009 & 0.019 & 0.023 \\
\hline Board Independence & -0.042 & 0.031 & 0.049 & 0.044 & 0.031 \\
\hline CEO Pay Slice & 0.020 & 0.022 & 0.022 & 0.018 & 0.016 \\
\hline CFO Pay Slice & -0.063 & -0.068 & -0.069 & -0.079 & -0.079 \\
\hline CFO Age & 0.042 & 0.043 & 0.027 & 0.031 & 0.030 \\
\hline CFO Tenure & $-0.132^{* *}$ & $-0.143^{\star *}$ & $-0.139^{* *}$ & $-0.158^{* * *}$ & $-0.161^{\text {*** }}$ \\
\hline Prior $\mathrm{CxO}$ Turnover & -0.002 & 0.019 & 0.013 & 0.027 & 0.023 \\
\hline Intercept & -0.800 & $-1.290^{*}$ & $-1.418^{*}$ & $-1.440^{*}$ & $-1.258^{*}$ \\
\hline Year Indicators & Yes & Yes & Yes & Yes & Yes \\
\hline Number of observations & 518 & 518 & 518 & 518 & 518 \\
\hline$p$-value for Wald $\chi^{2}$ & $<0.01$ & $<0.01$ & $<0.01$ & $<0.01$ & $<0.01$ \\
\hline Area Under ROC Curve & 0.687 & 0.698 & 0.709 & 0.717 & 0.714 \\
\hline
\end{tabular}

Note: ${ }^{* * *} p<0.01,{ }^{* *} p<0.05,{ }^{*} p<0.10$

of CFO turnover. These results provide strong support for Hypothesis 2. With regard to the influence of specific IT material weakness categories on CFO turnover, Models 4 and 5 (using, respectively, indicator and count variables) indicate that IT Control Oversight-Internal ( $p$-value $<0.01)$ to be a significant predictor-providing moderate support for Hypothesis 4.

To address potential concerns related to endogeneity, we performed the Heckman (1979) two-step procedure as an additional untabulated analysis. The first-stage probit regression model determines the likelihood of a firm having one or more IT material weaknesses. The sample for the first stage model includes all of the IT material weakness firms and their matched control firms. The dependent variable is equal to one if the firm reports IT material weaknesses, and zero otherwise. For the set of independent variables, we include $C I O$ reporting probability, CEO IT Expert, CFO IT Expert, Size, CEO as Chairman, Board Size, Board Independence, Auditor Office Size, Auditor Industry Specialist, Number of Non-IT Weaknesses, Audit Committee Effective, CEO Pay Slice, CFO Pay Slice, CEO Age, CFO Age, CEO Tenure, CFO Tenure, Growth, Leverage, and Institutional Ownership. 
From the first-stage probit regression, we calculate the inverse mills ratio (Lambda) - the ratio of the probability density function to the cumulative distribution function - and include it as an additional control variable in the second-stage CEO and CFO turnover probit regressions (Models $1-5$ in Tables 4 and 5). We find that the coefficient for the inverse mills ratio $($ Lambda) is not significant ( $p$-value $>0.10)$ in any of the second-stage regression models, suggesting that selection bias is not a concern. More importantly, the results pertaining to our main independent variables Number of IT Weaknesses and the five IT material weakness factors (IT Control OversightInternal, IT Capability, Software Development, IT Architecture, IT Control Oversight-External) remain qualitatively unchanged from the results reported in Tables 4 and 5. Overall, the results help alleviate concerns that our study's results are driven by endogeneity.

\section{Discussion}

Organizations' most senior executives face a conundrum regarding IT management. Because of personal limitations regarding time availability and IT expertise, executive leadership teams tend to delegate most, if not all, IT management responsibilities to a specialist-subordinate (e.g., a CIO). While mindfully undertaken managerial delegation is advantageous for both the delegating executive and this executive's organization, the delegating executive may suffer negative consequences if ineffectively handled delegated activities result in serious operational, regulatory/legal, or competitive vulnerabilities. However, little guidance currently exists to aid a senior executive in identifying the IT management responsibilities for which s/he is likely to be held accountable.

An especially prominent set of IT-related vulnerabilities in the post-SOX context are those associated with public firms' financial reporting processes. The identification of IT material weaknesses in a firm's SOX 404 reports raises the specter of SOX violations, potentially posing significant negative consequences for the firm (e.g., a loss of legitimacy) and for the firm's CEO and CFO (e.g., executive turnover).

Our empirical study has produced substantial evidence of heightened CEO and CFO turnover likelihoods when firms' SOX 404 reports identify IT material weaknesses. Importantly, CEOs and CFOs were observed to be selectively affected by serious IT deficiencies. For CEOs, deficiencies traced to IT Architecture and to IT Control OversightExternal were associated with higher turnover likelihoods. For CFOs, deficiencies traced to IT Control OversightInternal were associated with higher turnover likelihoods.
These findings provide empirical evidence supporting the often-voiced call for an organization's most senior executives to personally engage with IT management and clearly identify, within the financial reporting context, specific IT management responsibilities for CEOs and for CFOs.

These empirical results are largely consistent with our expectation that CEOs would be held accountable for global IT management responsibilities (i.e., IT Architecture) and that CFOs would be held accountable for demand-side IT management responsibilities (i.e., IT Control OversightInternal). However, two inconsistencies were observed. First, CEOs were also found to suffer a higher likelihood of turnover with IT Control Oversight-External deficiencies, which we had classified as a supply-side IT management responsibility. Second, serious deficiencies with IT Capability and with Software Development were not associated with higher CEO or CFO turnover likelihoods (or, with higher CIO turnover likelihoods). These two inconsistencies are now discussed.

As the component activities associated with IT Control Oversight-External (i.e., IT outsourcing and spreadsheet development) involve the direct handling of IT activities, we conceptualized it as a supply-side IT management responsibility for which CIOs would be accountable. As expected, we did find (see Appendix C) IT Control Oversight-External to influence CIO turnover. However, after controlling for the probability of CIO turnover, IT Control Oversight-External did influence the likelihood of CEO turnover. In retrospect, this outcome seems reasonable. Situations frequently arise where a CIO is unable to convince other senior executives (reporting upward to the CEO) to follow established global policies (in this case, policies regarding IT outsourcing or spreadsheet development). In such situations, only the CEO holds sufficient power to force compliance with contested global policies. Accordingly, we suggest that IT Control Oversight-External has two aspects: a supply-side aspect dealing with technical and operational concerns, and a global aspect dealing with strategic and policy concerns.

Neither IT Capability nor Software Development was observed to influence CEO or CFO (or CIO) turnover likelihoods. We offer two possible explanations. First, these results may be attributed to the financial reporting context: both IT Capability and Software Development, while important IT management responsibilities, might be too causally distant from the production of firm's financial reports. Different outcomes might very well be observed with other functional contexts. Second, these results may be attributed to the descriptions of IT material weaknesses in SOX 404 audit reports, to our coding of these data, and to the explora- 
tory factor analysis, each of which has comingled to some extent the demand-side and supply-side aspects of IT Capability and Software Development. Measurement procedures able to separate these demand-side and supply-side aspects might lessen the noise in our data set such that subsequent analyses would surface distinctive demand-side/supply-side influences for IT Capability and for Software Development.

\section{Limitations}

There are five major limitations to consider in interpreting our results. First, the SOX standards require substantial judgment on the part of the reporting firm and its auditors. A qualitatively similar control issue at one firm may have risen to the level of a material weakness and been included in our sample but may not have at another firm. To some extent, we were able to discount the consequences of variant auditor behavior by comparing the SOX 404 reports of "Big Four versus Other" external auditors without uncovering systematic effects (see footnote 16). However, more nuanced analysis might surface significant auditor biases. Second, our data examines the initial wave of SOX 404 reports (i.e., 20042007) which may prove markedly different than SOX 404 reports in subsequent time periods. Third, some of the executive turnover outcomes we report are likely to be voluntary. To address this possibility, we controlled for CEO age and for CFO age. Fourth, the derived IT material weakness categories were empirically determined (using data limited to the financial reporting context) rather than theoretically derived. Our categorical structure would certainly benefit from similar empirical efforts conducted in this and other functional contexts and from theoretical efforts aimed at developing comprehensive, compelling conceptualizations of senior executives' IT management responsibilities. Fifth, and perhaps most important, the implications of the current study are limited to hazards associated with the post-SOX financial reporting context. Numerous other types of IT risks exist (Smith et al. 2001; Tanriverdi and Ruefli 2004; Wallace et al. 2004) that similarly pose hazards for firms; we strongly encourage research examining senior executives' IT management responsibilities in other IT risk contexts.

\section{Contributions to Information Systems Research}

Nolan (2012) concluded his assessment of Boeing's IT management challenges with its 787 program by stating

The "elephant" in the Boeing board room, as well in the board rooms of many modern corporations, is ubiquitous IT spread throughout the corporation, but no IT strategic focus and leadership...important research questions must be addressed. First, what is the gestalt of a corporation's IT? Second, what should be the IT strategic focus? Third, what strategic IT leadership is required? Fourth, what action plan is required to execute the IT strategy? (p. 101).

This study's conceptualizations and empirical findings make two important contributions to our discipline's establishing a new gestalt regarding IT management.

First, we anticipate that our work will initiate a recasting of how our discipline thinks about IT management, especially with regard to terms such as IT strategy and IT leadership. Today, customer-, product-, and process-driven competitive positions and strategic actions (i.e., demand-side issues) are increasingly formulated through IT-infused cognitions and implemented via robust business platforms and robust digital platforms applying, as appropriate, well-conceived and timely digital innovations (Sambamurthy and Zmud 2015). But IT strategy and IT leadership are as well needed elsewhere if sought competitive positions are to be achieved and if taken strategic actions are to be successful: cross-unit and extraorganizational IT-related synergies need to be identified, constituted, and coordinated (e.g., global issues); and efficient, effective, secure, and agile business/digital platforms need to be designed, fabricated, implemented, operated, and evolved (i.e., supply-side issues). IT management thus is best conceived of as a polycentric, rather than monocentric, activity system (Constantinides and Barrett 2015).

As an illustration of a polycentric view of IT management, consider the ideal IT management profiles identified by Guillemette and Pare (2012): partner, system provider, architecture builder, technology leader and project coordinator. Applying a monocentric perspective on IT management characteristic of our discipline, Guillemette and Pare argue that organizations' leaders should first identify and then adopt that profile which best aligns with three contingency factors: how IT is perceived by top management, how the CIO is perceived by top management, and how IT-literate are top management. Our perspective is quite different. Polycentric IT management assumes the existence of numerous distinct, but interrelated, IT management activity systems (e.g., within the office of the CEO, within offices of business unit presidents, within the offices of functional executives, within the offices of IT executives, etc.), each of which holds unique IT management responsibilities requiring various combinations of the capabilities represented by the five ideal IT management profiles. We expect systematic variation will be observed both in the number and natures of distinct IT 
management activity systems across differing types of organizations and in the nature of the capability profiles observed across distinct types of IT management activity systems. We strongly encourage theoretical and empirical research that assesses these expectations.

Second, interweaving our ideas regarding organizations' polycentric IT management activity systems with research examining senior executives' IT-related structural, cognitive, and relational social capitals (Preston and Karahanna 2009) promises to provide a rich conceptual schema with which to envision and portray the new gestalt regarding polycentric $I T$ management. If the ideas we raise hold merit, particular groupings of executives and managers should be brought together in directing, monitoring, and, as needed, redirecting specific IT management activities. In other words, we posit that the organizations seen as being successful in their deployment of IT will have established numerous "systems of knowing" (Armstrong and Sambamurthy 1999) constellations, with each constellation focused on specific IT management activities and involving that group of executives/managers holding an appropriate assemblage of industry, business, and technology knowledge/insight. Importantly, establishing these groups is likely to involve (1) the use of temporal and topical interlocks (Sambamurthy and Zmud 2015) that introduce, respectively, a group's organizational memory and an awareness of other groups' actions into ensuing deliberations and (2) a layered nesting of related groups that gives "autonomy to all stakeholders to govern themselves as long as their self-governance does not affect others in the same or higher layers" (Constantinides and Barret 2015, p. 54). We strongly encourage research that examines (1) the existence and nature of such system of knowing constellations, (2) how these constellations are established, operated, and evolved, (3) how interdependencies across the constellations are handled, and (4) best practices exhibited by constellation participants in producing exceptional performance outcomes.

\section{Contributions to Management Research}

Applying arguments related to stigmatization as a consequence of organizations' loss of legitimacy (Wiesenfeld et al. 2008) and working within the post-SOX financial reporting context, Arthaud-Day et al. (2006) linked CEO and CFO turnover events to a specific organizational failure event: a public firm's financial restatement. By explaining CEO and CFO turnover as a consequence of this specific negative event for which CEOs and CFOs are explicitly held accountable, Arthaud-Day et al. reduced the causal ambiguity previously found to characterize the relationship between poor organizational performance and executive turnover. Our work further reduces this causal ambiguity by positing and con- firming CEO and CFO accountabilities for distinct IT management responsibilities.

Our work also contributes to research on managerial delegation by clarifying the nature of a delegating executive's retained accountabilities. We offer two insights. First, stakeholders are likely to hold an executive filling a general manager role accountable for performance failures regarding (1) the preservation of strategic flexibility and (2) the upholding of organization-wide or unit-wide (for unit-level executives) strategies and policies. Second, stakeholders are likely to hold an executive filling a functional manager role accountable for performance failures regarding a functional domain's strategic or operational effectiveness.

\section{Implications for Information Systems Practice}

While our findings support the often-voiced admonition for senior executives to personally engage with IT management activities, we refine this admonition by advocating that senior executives holding particular managerial roles should, pragmatically, personally engage with specific, but not all, IT management activities. It thereby becomes critically important for an organization's IT function to recognize which senior executives need to be kept aware of which IT management activities and then to devise appropriate reporting systems. But, designing executive-focused IT management reporting systems is fraught with challenges, including but not limited to presenting complex, technical content such that provisioned content addresses the issues most relevant to a particular senior executive and is understood by this executive; meaningfully placing reported information within constantly shifting business and technology landscapes; and accurately characterizing associated risks along with the statuses of in-place risk management structures, tactics, and actions.

For the most part, little scholarly research has been directed at executive-focused IT management reporting systems. An exception is work by Mitra et al. (2011) that suggests a portfolio of metrics to be communicated by the IT function to an organization's senior executives. We advocate future research that extends the Mitra el al. portfolio of metrics, tailors such metrics to meet the needs of particular senior executives, empirically assesses the meaningfulness of such metrics, and exposes the weaknesses of alternative designs for presenting technical information to senior executives.

A second important responsibility of an organization's IT function involves the IT function's leadership team working with the organization's executive leadership team to design 
and implement a polycentric IT governance system (Constantinides and Barrett 2015) that engages particular senior executives in specific IT management activity systems. Here, implemented governance structures and processes should be designed such that minimal demands are placed on senior executives while still enabling the executives to direct, monitor and, if needed, redirect associated IT-related activities. While considerable research exists on IT governance systems (e.g., Fonstad and Robertson 2006; Huang et al. 2010; Ross et al. 2006; Schwarz and Hirschheim 2003; Weill 2004; Williams and Karahanna 2013), the lenses that have been applied have not examined the roles or obligations of particular senior executives - or, to be precise, of particular groups of senior executives-regarding specific IT management activities. We encourage future research that applies such a lens.

\section{Conclusion}

We undertook this study to answer the question: For which IT management responsibilities are particular senior executives held accountable for serious IT deficiencies? Our empirical findings establish that CEOs and CFOs are, in fact, held accountable for distinct, serious IT deficiencies. While our study is couched within a financial reporting context, we are confident that comparable findings would be observed in other organizational contexts. In describing the implications of our work, we offer a fresh gestalt regarding IT management. We sincerely hope that our ideas, findings, and suggestions for future research gain traction with other scholars such that collective progress is made in improving our understanding of IT management within today's organizational contexts.

\section{References}

Adams, J. S. 1963. "Toward an Understanding of Inequity," Journal of Abnormal and Social Psychology (67:5), pp. 422-436.

Armstrong, C. F., and Sambamurthy, V. 1999. "Information Technology Assimilation in Firms: The Influence of Senior Leadership and IT Infrastructures," Information Systems Research (10:4), pp. 304-327.

Arrow, K. 1974. The Limits of Organizations, New York: Norton. Arthaud-Day, M. L., Cerro, S. T., Dalton, C. M., and Dalton, D. R. 2006. "A Changing of the Guard: Executive and Director Turnover Following Corporate Financial Restatements,' Academy of Management Journal (49:6), pp. 1119-1136.

Ashbaugh-Skaife, H., Collins, D. W., and Kinney Jr., W. R. 2007. "The Discovery and Reporting of Internal Controls Prior to SOXMandated Audits," Journal of Accounting and Economics (44:1/2), pp. 166-192.
Banker, R. D., Hu, N., Pavlou, P. A., and Luftman, J. 2011. "CIO Reporting Structure, Strategic Positioning, and Firm Performance," MIS Quarterly (35:2), pp. 487-504.

Barnard, C. 1938. The Functions of the Executive, Cambridge, MA: Harvard University Press.

Barney, J. 1991. "Firm Resources and Sustained Competitive Advantage," Journal of Management (17:1), pp. 99-120.

Bebchuk, L. A., Martijn Cremers, K. J, and Peyer, U. C. 2011. "CEO Pay Slice," Journal of Financial Economics (102:1), pp. 199-221.

Beneish, M. D., Billings, M. B., and Holder, L. D. 2008. "Internal Control Weaknesses and Information Uncertainty," The Accounting Review (83:3), pp. 665-704.

Bensaou, M., and Earl, M. 1998. "The Right Mind Set for Managing Information Technology," Harvard Business Review (76:5), pp. 119-128.

Blau, P. M., and Scott, R. W. 1962. Formal Organizations, San Francisco: Scott Foresman.

Bharmornsiri, S., Guinn, R., and Schroeder, R. G. 2009. "International Implications of the Cost of Compliance with the External Audit Requirements of Sarbanes-Oxley," International Advances in Economic Research (15:1), pp. 17-29.

Boeker, W. 1992. "Power and Managerial Dismissal: Scapegoating at the Top," Administrative Science Quarterly (37:3), pp. 400-421.

Boynton, A. C., Jacobs, G. C., and Zmud, R. W. 1991. "Whose Responsibility is IT (Information Technology) Management?," Sloan Management Review (33:4), pp. 32-38.

Brown, C., and Vessey, I. 2003. "Managing the Next Wave of Enterprise Systems: Leveraging Lessons from ERP," MIS Quarterly Executive (2:1), pp. 45-57.

Canada, J., Sutton, S. G., and Kuhn, J. R. 2009. "The Pervasive Nature of IT Controls: An Examination of Material Weaknesses in IT Controls and Audit Fees," International Journal of Accounting and Information Management (17:1), pp. 106-119.

Carpenter, M. A., Geletkanycz, M. A., and Sanders, W. G. 2004. "Upper Echelons Research Revisited: Antecedents, Elements, and Consequences of Top Management Team Composition," Journal of Management (30:6), pp. 749-778.

Carpenter, M. A., and Wade, J. B. 2002. "Microlevel Opportunity Structures as Determinants of Non-CEO Executive Pay," Academy of Management Journal (45:6), pp. 1085-1103.

Castanias, R. P., and Helfat, C. E. 2001. "The Managerial Rents Model: Theory and Empirical Analysis," Journal of Management (27:6), pp. 661-678.

Chandler, A. 1962. Strategy and Structure: Chapters in the History of the Industrial Enterprise, Cambridge, MA: MIT Press.

Chatterjee, D., Richardson, V. J., and Zmud, R. W. 2001. "Examining the Shareholder Wealth Effects of Announcements of Newly Created CIO Positions," MIS Quarterly (25:1), pp. 43-70.

Chen, D. Q., Preston, D. S., and Xia, W. 2010. "Antecedents and Effects of CIO Supply-Side and Demand-Side Leadership: A Staged Maturity Model," Journal of Management Information Systems (27:1), pp. 231-272.

Coase, R. H. 1937. "The Nature of the Firm," Economica (4:16), pp. 386-405.

Collins, D., Masli, A., Reitenga, A. L., and Sanchez, J. M. 2009. "Earnings Restatements, the Sarbanes-Oxley Act and the 
Disciplining of Chief Financial Officers," Journal of Accounting, Auditing and Finance (24:1), pp. 1-34.

Constantinides, P., and Barrett, M. 2015. "Information Infrastructure Development and Governance as Collective Action," Information Systems Research (26:1), pp. 40-56.

Cyert, R. M., and March, J. G. 1963. A Behavioral Theory of the Firm, Englewood Cliffs, NJ: Prentice-Hall.

Dalton, M. 1959. Men Who Manage, New York: Wiley.

Davenport, T. H., and Beck, J. C. 2013. The Attention Economy: Understanding the New Currency of Business, Boston: Harvard Business Press.

Desai, H., Hogan, C., and Wilkins, M. 2006. "The Reputational Penalty for Aggressive Accounting: Earnings Restatements and Managerial Turnover," The Accounting Review (81:1), pp. 83-112.

Doyle, J., Ge, W., and McVay, S. 2007. "Determinant of Weaknesses in Internal Control Over Financial Reporting," Journal of Accounting and Economics (44:1/2), pp. 193-223.

Eilifsen, A., and Messier Jr., W. F. 2000. "The Incidence and Detection of Misstatements: A Review and Integration of Archival Research," Journal of Accounting Literature (19), pp. $1-43$.

El Sawy, O. A., and Pavlou P. 2008. "IT-Enabled Business Capabilities for Turbulent Environments," MIS Quarterly Executive (7:3), pp. 57-68.

Fama, E. F. 1980. "Agency Problems and the Theory of the Firm," The Journal of Political Economy (88:2), pp. 288-307.

Fama, E. F., and Jensen, M. C. 1983. "Separation of Ownership and Control," The Journal of Law and Economics (26:2), pp. 301-326.

Feeney, D. F., Edwards, B. R., and Simpson, K. M. 1992. "Understanding the CEO/CIO Relationship," MIS Quarterly (16:4), pp. 435-448.

Feeney, D. F., and Willcocks, L. P. 1998. "Core IS Capabilities for Exploiting Information Technology," Sloan Management Review (39:3), pp. 9-21.

Feld, C. S., and Stoddard, D. B. 2004. "Getting IT Right," Harvard Business Review (82:2), pp. 72-79.

Finkelstein, S., Hambrick, D. C., and Cannella, A. A. 2009. Strategic Leadership: Theory and Research on Executives, Top Management Teams, and Boards, New York: Oxford University Press.

Fonstad, N. O., and Robertson, D. 2006. "Transforming a Company, Project by Project: The IT Engagement Model," MIS Quarterly Executive (5:1), pp. 1-14.

Furtado, E. P. H., and Karan, V. 1990. "Causes, Consequences, and Shareholder Wealth Effects of Management Turnover: A Review of the Empirical Evidence," Financial Management (19:2), pp. $60-75$.

Galbraith, J. 1973. Designing Complex Organizations, Boston: Addison-Wesley Longman.

Gore, A. K., Matsunaga, S, and Yeung, P. E. 2010. "The Role of Technical Expertise in Firm Governance Structure: Evidence from Chief Financial Officer Contractual Incentives," Strategic Management Journal (32:7), pp. 771-786.

Grant, G. H., Miller, K. C., and Alali, F. 2008. "The Effect of IT Controls on Financial Reporting," Managerial Auditing Journal (23:8), pp. 803-823

Grant, R. M. 1996. "Toward a Knowledge-Based Theory of the Firm,” Strategic Management Journal (17:S1), pp. 109-122.
Guadalupe, M., Li, H., and Wulf, J. 2014. "Who Lives in the CSuite? Organizational Structure and the Division of Labor in Top Management," Management Science (60:4), pp. 824-844.

Guillemette, M. G., and Paré, G. 2012. "Toward a New Theory of the Contribution of the IT Function in Organizations," MIS Quarterly (36:2), pp.529-551.

Hambrick, D. C. 2007. "Upper Echelons Theory: An Update," Academy of Management Review (32:2), pp. 334-343.

Hambrick, D. C., Finkelstein, S., and Mooney, A. C. 2005. "Executive Job Demands: New Insights for Explaining Strategic Decisions and Executive Behaviors," Academy of Management Review (30:3), pp. 472-491.

Hambrick, D. C., and Mason, P. A. 1984. "Upper Echelons: The Organization as a Reflection of its Top Managers," Academy of Management Review (9:2), pp. 193-206.

Hammersley, J. S., Myers, L. A., and Shakespeare, C. 2008. "Market Reactions to the Disclosure of Internal Control Weaknesses and to the Characteristics of those Weaknesses under Section 302 of the Sarbanes Oxley Act of 2002," Review of Accounting Studies (13:1), pp. 141-165.

Heckman, J. J. 1979. "Sample Selection Bias as a Specification Error," Econometrica: Journal of the Econometric Society (47:1), pp.153-161.

Hirschheim, R., Welke, R., and Schwartz, A. 2010. "ServiceOriented Architecture: Myths, Realities, and a Maturity Model," MIS Quarterly Executive (9:1), pp. 37-48.

Hoitash, R., Hoitash, U., and Johnstone, K. M. 2012. "Internal Control Material Weaknesses and CFO Compensation," Contemporary Accounting Research (29:3), pp. 768-803.

Hsu, A. W., and Liao, C. 2012. "Do Compensation Committees Pay Attention to Section 404 Opinions of the Sarbanes-Oxley Act?," Journal of Business Finance \& Accounting (39:9/10), pp. 1240-1271.

Huang, R., Zmud, R. W., and Price, R. L. 2010. "Influencing the Effectiveness of IT Governance Practices through Steering Committees and Communication Policies," European Journal of Information Systems (19:3), pp. 288-302.

ITGI. 2004. IT Control Objectives for Sarbanes-Oxley: The Importance of IT in the Design, Implementation and Sustainability of Internal Control over Disclosure and Financial Reporting, Rolling Meadows, IL: IT Governance Institute.

ITGI. 2005. The CEO's Guide to IT Value@Risk, Rolling Meadows, IL: IT Governance Institute.

ITGI. 2007. $C O B I T ® ~ 4.1$, Rolling Meadows, IL: IT Governance Institute (available at http:/www.isaca.org/Knowledge-Center/ cobit/Pages/Downloads.aspx; registration required).

ITGI. 2008. Enterprise Value: Governance of IT investments, Rolling Meadows, IL: IT Governance Institute.

Jarvenpaa, S. L., and Ives, B. 1991. "Executive Involvement and Participation in the Management of Information Technology," MIS Quarterly (15:2), pp. 205-227.

Jensen, M. C. 1993. "The Modern Industrial Revolution, Exit and the Failure of Internal Control Systems," Journal of Finance (48:3), pp. 831-880.

Jensen, M. C., and Meckling, W. 1976. "Theory of the Firm: Managerial Behavior, Agency Costs, and Capital Structure," Journal of Financial Economics (3:4), pp. 305-360.

Kearns, G. S., and Sabherwal, R. 2007. "Antecedents and Consequences of Information Systems Planning Integration," IEEE Transactions on Engineering Management (54:4), pp. 628-643. 
Kettinger, W. J., Marchand, D. A., and Davis, J. M. 2010. "Designing Enterprise Architectures to Optimize Flexibility and Standardization in Global Business," MIS Quarterly Executive (9:2), pp. 95-113.

Klamm, B. K., and Watson, M. W. 2009. "SOX 404 Reported Internal Control Weaknesses: A Test of COSO Framework and Information Technology," Journal of Information Systems (23:2), pp. 1-24.

Klamm, B. K., Kobelsky, K. W., and Watson, M. W. 2012. "Determinants of the Persistence of Internal Control Weaknesses," Accounting Horizons (26:2), pp. 307-333.

Kogut, B., and Zander, U. 1992. "Knowledge of the Firm, Combinative Capabilities and the Replication of Technology," Organization Science (3:3), pp. 383-397.

Kohli, R., and Johnson, S. 2011. "Digital Transformation in Latecomer Industries: CO and CEO Leadership Lessons from Encana Oil \& Gas (USA) Inc.," MIS Quarterly Executive (10:4), pp. 141-156.

Leana, C. R. 1986. "Predictors and Consequences of Delegation," Academy of Management Journal (29:4), pp. 754-774.

Leonard-Barton, D., and Deschamps, I. 1988. "Managerial Influence in the Implementation of New Technology," Management Science (34:10), pp. 1252-1265.

Li, C., Peters, G., Richardson, V. J., and Watson, M. W. 2012. "The Consequences of Information Technology Control Weaknesses on Management Information Systems: The Case of Sarbanes-Oxley Internal Control Reports," MIS Quarterly (36:1), pp. 179-203.

Li, C., Sun, L., and Ettredge, M. 2010. "Financial Executive Qualifications, Financial Executive Turnover and Adverse SOX 404 Opinions," Journal of Accounting and Economics (50:1), pp. 93-110.

Liang, H., Saraf, N., Hu, Q., and Xue, Y. 2007. “Assimilation of Enterprise Systems: The Effect of Institutional Pressures and the Mediating Role of Top Management," MIS Quarterly (31:1), pp. 59-87.

Lippman, S. A., and Rumelt, R. P. 2003. “A Bargaining Perspective on Resource Advantage," Strategic Management Journal (24:11), pp. 1069-1086.

Marcel, J. J. 2009. "Why Top Management Team Characteristics Matter When Employing a Chief Operating Officer: A Strategic Contingency Perspective," Strategic Management Journal (30:6), pp. 647-658.

March, J., and Simon, H. 1958. Organizations, New York: John Wiley \& Sons.

Martin, B. L., Batcheldor, G., Newcomb, J., Rockart, J. F., Yetter, W. P., and Grossman, J. G. 1995. "The End of Delegation? Information Technology and the CEO," Harvard Business Review (73:5), pp. 161-172.

Milgrom, P., and Roberts, J. 1990. "The Economics of Modern Manufacturing: Technology, Strategy, and Organization," American Economic Review (80:3), pp. 511-528.

Mitra, S., Sambamurthy, V., and Westerman, G. 2011. "Measuring IT performance and Communicating Value," MISQ Executive (10:1), pp. 47-59.

Monteverde, K. 1995. "Technical Dialog as an Incentive for Vertical Integration in the Semiconductor Industry," Management Science (41:10), pp. 1621-1638.

Murphy, K. J., and Zimmerman, J. L. 1993. "Financial Performance Surrounding CEO Turnover," Journal of Accounting and Economics (16:1/2/3), pp. 273-315.
Nadkarni, S., and Hermann, P. 2010. "CEO Personality, Strategic Flexibility, and Firm Performance: The Case of the Indian Business Process Outsourcing Industry," Academy of Management Journal (53:5), pp. 1050-1073.

Nolan, R. L. 2012. "Ubiquitous IT: The Case of the Boeing 787 and Implications for Strategic IT Research," Journal of Strategic Information Systems (21:2), pp. 91-102.

Ouchi, W. G. 1980. "Markets, Bureaucracies, and Clans," Administrative Science Quarterly (25:1), pp. 129-141.

Palmrose, Z-V, Richardson, V. R., and Scholz, S. 2004. "Determinants of Market Reactions to Restatement Announcements," Journal of Accounting and Economics (37:1), pp. 59-89.

Penrose, E. T. 1959. The Theory of the Growth of the Firm, New York: Oxford University Press.

Pfeffer, J. 1981. Power in Organizations, Marshfield, MA: Pitman.

Pfeffer, J., and Salancik, G. 1978. The External Control of Organizations, New York: Harper \& Row.

Pralahad, C. K., and Krishnan, M. S. 2002. "The Dynamic Synchronization of Strategy and Information Technology," Sloan Management Review (43:4), pp. 24-33.

Prentice, R. 2007. "Sarbanes-Oxley: The Evidence Regarding the Impact of SOX 404," Cardoza Law Review (29:2), pp. 703-764.

Preston, D. S., and Karahanna, E. 2009. "Antecedents of IT Strategic Alignment: A Nomological Network," Information Systems Research (20:2), pp. 159-179.

PCAOB. 2004. Auditing Standard No.2: An Audit of Internal Control over Financial Reporting That Is Integrated with an Audit of Financial Statements, Washington, DC: Public Company Accounting Oversight Board (available at http://pcaobus. org/Standards/Auditing/Pages/Auditing_Standard_2.aspx).

PCAOB. 2007. Auditing Standard No.5: an Audit of Internal Control over Financial Reporting That Is Integrated with an Audit of Financial Statements, Washington, DC: Public Company Accounting Oversight Board (available at http://pcaobus. org/Standards/Auditing/Pages/Auditing_Standard_5.aspx).

Puffer, S. M., and Weintrop, J. B. 1991. "Corporate Performance and CEO Turnover: The Role of Performance Expectations," Administrative Science Quarterly (36:1), pp. 1-19.

Purvis, R. L., Sambamurthy, V., and Zmud, R. W. 2001. "The Assimilation of Knowledge Platforms in Organizations: An Empirical Investigation," Organization Science (12:2), pp. 117-135.

Rockart, J. F. 1988. "The Line Takes the Leadership-IS Management in a Wired Society," Sloan Management Review (29:4), pp. 57-64.

Ross, J. W. 2003. "Creating a Strategic IT Architecture Competency: Learning in Stages," MIS Quarterly Executive (2:1), pp. 31-43.

Ross, J. W., and Weill, P. 2002. "Six IT Decisions Your IT People Shouldn't Make," Harvard Business Review (80:11), pp. 84-91.

Ross, J. W., Weill, P., and Robertson, D. C. 2006. Enterprise Architecture as Strategy: Creating a Foundation for Business Execution, Boston: Harvard Business School Press.

Sambamurthy, V., and Zmud, R. W. 2012. Guiding the Digital Transformation of Organizations, Tallahassee, FL: Legerity Digital Press.

Sambamurthy, V., and Zmud, R. W. 2015. Business Platforms, Digital Platforms and Digital Innovation: An Executive Agenda, Tallahassee, FL: Legerity Digital Press. 
Scholz, S. 2008. "The Changing Nature and Consequences of Public Company Financial Restatements: 1997-2006," Washington, DC: U.S. Department of the Treasury (available at http://www.esnai.com/upload_files/0/200842419121449520.pdf).

Schwarz, A., and Hirschheim, $\bar{R}$. 2003. “An Extended Platform Logic Perspective of IT Governance: Managing Perceptions and Activities of IT," Journal of Strategic Information Systems (12), pp. 129-166.

SEC. 2003. Final Rule: Management's Reports on Internal Control Over Financial Reporting and Certification of Disclosure in Exchange Act Periodic Reports, Washington, DC: Securities and Exchange Commission (available at http://www. sec.gov/rules/final/33-8238.htm).

Sharma, R., and Yetton, P. 2003. "The Contingent Effects of Management Support and Task Interdependence on Successful Information Systems Implementation," MIS Quarterly (27:4), pp. 533-555.

Shen, W., and Cannella, A. A. 2002. "Power Dynamics Within Top Management and Their Impacts on CEO Dismissal Followed by Inside Succession," Academy of Management Journal (45:6), pp. 1195-1206.

Shpilberg, D., Berez, S., Puryear, R., and Shah, S. 2007. "Avoiding the Alignment Trap in Information Technology," MIT Sloan Management Review (49:1), pp. 51-58.

Simon, H. A. 1947. Administrative Behavior, London: Free Press.

Sinclair, A. 1995. "The Chameleon of Accountability: Forms and Discourses," Accounting, Organizations and Society (20:2/3), pp. 219-237.

Smith, H. A., McKeen, J. D., and Staples, D. S. 2001. "Risk Management in Information Systems: Problems and Potential," Communications of the AIS (7:1), Article 13.

Smith, H. A., McKeen, J. D., Cranston, C., and Benson, M. 2010. "Investment Spend Optimization: A New Approach to IT Investment at BMO Financial Group," MIS Quarterly Executive (9:2), pp. 65-81.

Sondergaard, P. 2014. "The CEO's D-Business Dilemma," Forbes, June 2 (http://www.forbes.com/sites/gartnergroup/2014/06/02/ the-ceos-d-business-dilemma/).

Tallon, P. P., and Pinsoneault, A. 2011. "Competing Perspectives on the Link Between Strategic Information Technology Alignment and Organizational Agility: Insights from a Mediation Model," MIS Quarterly (35:2), pp. 463-486.

Tanriverdi, H., and Ruefli, T. W. 2004. "The Role of Information Technology in Risk/Return Relations in Firms," Journal of the AIS (5:11-12), pp. 421-447.

Uzzi, B. 1996. "The Sources and Consequences of Embeddedness for the Economic Performance of Organizations," American Sociological Review (61:4), pp. 674-698.

Wagner, W. G., Pfeffer, J., and O'Reilly, C. 1984. "Organizational Demography and Turnover in Top Management Groups," Administrative Science Quarterly (29:1), pp. 74-92.

Wallace, L., Keil, M., and Rai, A. 2004. "How Software Project Risk Affects Project Performance: An Investigation of the Dimensions of Risk and an Exploratory Model," Decision Sciences (35:2), pp. 289-321.

Wang, X. 2010. "Increased Disclosure Requirements and Corporate Governance Decisions: Evidence from Chief Financial Officers in the Pre-and Post-Sarbanes-Oxley Periods," Journal of Accounting Research (48:4), pp. 885-920.

Warner, J., Watts, R., and Wruck, K. 1988. "Stock Price Drops and Management Changes," Journal of Financial Economics (20:1), pp. 461-492.
Weill, P. 2004. "Don't Just Lead, Govern: How Top-Performing Firms Govern IT," MIS Quarterly Executive (3:4), pp. 1-17.

Weisbach, M. 1988. "Outside Directors and CEO Turnover," Journal of Financial Economics (20:1), pp. 431-460.

Williams, C. K., and Karahanna, E. 2013. "Causal Explanation in the Coordinating Process: A Critical Realist Case Study of Federated IT Governance Structures," MIS Quarterly (37:3), pp. 933-964.

Wiesenfeld, B. M., Wurthmann, K. A., and Hambrick, D. C. 2008. "The Stigmatization and Devaluation of Elites Associated with Corporate Failures: A Process Model," Academy of Management Review (33:1), pp. 231-251.

Wood, R., Bandura, A., and Bailey, T. 1990. "Mechanisms Governing Organizational Performance in Complex DecisionMaking Environments," Organizational Behavior and Human Decision Performance (46:2), pp. 181-201.

Yermack, D. 1996. "Higher Market Valuations of Companies with a Small Board of Directors," Journal of Financial Economics (40:2), pp. 185-211.

Yukl, G., and Fu, P. P. 1999. "Determinants of Delegation and Consultation by Managers," Journal of Organizational Behavior (20:2), pp. 219-232.

Zenger, T. R., Felin, T., and Bigelow, L. 2011. "Theories of the Firm-Market Boundary," Academy of Management Annals (5:1), pp. 89-133.

Zhang, Y., and Rajagopalan, N. 2004. "When the Known Devil Is Better than an Unknown God: An Empirical Study of the Antecedents and Consequences of Relay CEO Successions," Academy of Management Journal (47:4), pp. 483-500.

\section{About the Authors}

Adi Masli is an assistant professor of Accounting and Information Systems in the School of Business at the University of Kansas. His primary areas of research are business value of IT, the role of IT in financial reporting and disclosure, and IT governance. He holds a Ph.D. (Accounting) from the University of Arkansas.

Vernon Richardson is the S. Robson Walton Chair in Accounting at the University of Arkansas. He is also a research fellow at Xi' an Jiaotong Liverpool University. His research interests include the business value of information technology investments and the accounting impact of information technology. He holds a Ph.D. (Accounting) from the University of Illinois.

Marcia Weidenmier Watson is an associate professor at the University of North Carolina at Charlotte. She received her Ph.D. in Accounting from the University of Texas at Austin. Her research interests include information technology, internal controls, business processes, and auditing.

Robert Zmud is a George Lynn Cross Research Professor Emeritus in the Michael F. Price College of Business at the University of Oklahoma. His research interests focus on information technology management and on technology adoption and use. He holds a Ph.D. (Management) from the University of Arizona. 


\title{
SENIOR EXECUTIVES' IT MANAGEMENT RESPONSIBILITIES: SERIOUS IT-RELATED DEFICIENCIES AND CEO/CFO TURNOVER
}

\author{
Adi Masli \\ School of Business, University of Kansas, 350-N Summerfield, 1300 Sunnyside Avenue, \\ Lawrence, KS 6604590089 U.S.A. \{amasli@ku.edu\}
}

Vernon J. Richardson

Sam M. Walton College of Business, University of Arkansas, Fayetteville, AR 02452 U.S.A. \{vrichardson@walton.uark.edu\} and Xi'an Jiaotong Liverpool University, Suzhou, Jiangsu, CHINA \{Vernon.Richardson@xjtlu.edu.cn\}

Marcia Weidenmier Watson

Belk College of Business, University of North Carolina at Charlotte, 9201 University City Boulevard, Charlotte, NC 28223-0001 U.S.A. \{mwatson40@uncc.edu\}

Robert W. Zmud

Price College of Business, University of Oklahoma, 307 W. Brooks,

Norman, OK 73019 U.S.A. \{rzmud@ou.edu\}

\section{Appendix A}

\section{The Sarbanes-Oxley Act of 2002 and CEO/CFO Accountability}

The Sarbanes-Oxley Act of 2002 (SOX) was established to strengthen internal controls over financial reporting by U.S. public firms and, as a consequence, to increase investor and stakeholder confidence in published financial reports. Among the many SOX provisions, SOX 404 requires an annual assessment by the firm's executive management and external auditor of the firm's internal controls over financial reporting (SEC 2003). The U.S. Securities and Exchange Commission (SEC) formally defines internal controls over financial reporting as (SEC 2003: Section II.A.3.):

\begin{abstract}
A process designed by, or under the supervision of, the registrant's principal executive and principal financial officers, or persons performing similar functions, and effected by the registrant's board of directors, management and other personnel, to provide reasonable assurance regarding the reliability of financial reporting and the preparation of financial statements for external purposes in accordance with generally accepted accounting principles.
\end{abstract}

The SOX regulation, thus, requires a firm's executive management to make an annual assessment on the effectiveness of the firm's internal controls. This process typically consists of the following: (1) identifying significant financial systems (i.e., identify systems that process accounts exceeding materiality thresholds); (2) documenting each system's internal controls using narratives, questionnaires, and/or flowcharts; (3) confirming an understanding of step 2 by conducting walkthroughs (i.e., follow transactions through the systems and all control points to make sure that all internal controls are working); (4) assessing the risk of material misstatement within each financial system; (5) identifying the key controls over financial reporting; and (6) testing these key controls. Management documents its assessment on the effectiveness of controls, including the existence of material weaknesses, in the Annual Report in Item 9A, "Management's Report on Internal Controls over Financial Reporting." If one or more material weaknesses exist, internal controls are not considered to be effective. 
For accelerated and large accelerated firms, SOX 404 also requires that external auditors attest to management's assessment of internal controls as part of the annual financial statement audit. Auditors follow the same basic steps described in the prior paragraph and may rely on documentation provided by management. Auditors must issue their own report on the effectiveness of internal controls and, if any material weaknesses exist, the auditor must express an adverse opinion on internal controls over financial reporting and identify these material weaknesses in the audit report. The presence of a material weakness, thus, should first be identified by management and then verified by the external auditor.

The SOX provisions require that the CFO and CEO be held responsible for executing their fiduciary duties (i.e., establishing and maintaining their firm's internal controls regarding financial reporting) (Hoitash et al. 2012). The executive management of firms for which material weaknesses have been reported is likely to be seen as having underperformed these fiduciary responsibilities and, as a result, may face disciplinary actions including legal sanctions and nonlegal penalties (e.g., job terminations and subsequent difficulties in obtaining comparable managerial positions). The SOX regulations can impose legal sanctions of up to a $\$ 5$ million fine and/or up to 20 years in prison (Geiger and Taylor 2003) on CEOs and CFOs implicated in fraudulent financial reporting. Nonlegal penalties can also affect CEOs and CFOs of firms disclosing SOX-related material weaknesses. For example, Beneish et al. (2008) found firms identified as having disclosed material weaknesses to have experienced significant stock price declines, and Li et al. (2010) find such firms to have experienced a significantly higher rate of CFO turnover.

\section{Appendix B}

\section{Exploratory Factor Analysis and COBIT Mapping}

Using count variables for each of the 16 identified IT material weaknesses, we applied principal component analysis with varimax rotation. Only factors with an eigenvalue greater than 1 were retained, and an IT material weakness was associated with a factor if its loading was greater than 0.40. Two of these 16 IT material weaknesses (lack of control and lack of documentation) were observed to load on multiple factors; these two IT material weaknesses were consequently dropped from further factor analysis. The factor analysis of the remaining 14 IT material weaknesses produced the factor structure presented in Table B1. Bolded and underlined IT material weakness coefficients indicate those associated with each IT material weakness category (or, factor).

\begin{tabular}{|c|c|c|c|c|c|}
\hline \multirow[b]{2}{*}{ IT Material Weakness Items } & \multicolumn{5}{|c|}{ Exploratory Factor Structure } \\
\hline & \begin{tabular}{|c|} 
IT Control \\
Oversight-Internal
\end{tabular} & $\begin{array}{c}\text { IT } \\
\text { Capability }\end{array}$ & $\begin{array}{c}\text { Software } \\
\text { Development }\end{array}$ & $\begin{array}{c}\text { IT } \\
\text { Architecture }\end{array}$ & $\begin{array}{c}\text { IT Control } \\
\text { Oversight-External }\end{array}$ \\
\hline Segregation of Duties & $\underline{0.723}$ & 0.14 & -0.114 & -0.081 & -0.096 \\
\hline Backup/Recovery/Security & 0.579 & -0.152 & 0.171 & -0.077 & 0.24 \\
\hline Access Control & 0.759 & 0.048 & -0.159 & -0.071 & -0.098 \\
\hline IT Management Oversight & 0.645 & 0.244 & 0.204 & -0.024 & 0.173 \\
\hline IT Skillbase & 0.28 & $\underline{0.655}$ & 0.115 & -0.013 & -0.143 \\
\hline Business Analysis & -0.248 & 0.493 & 0.234 & 0.008 & 0.273 \\
\hline Infrastructure/Operations & 0.129 & 0.768 & -0.222 & 0.054 & -0.083 \\
\hline Software Development & 0.395 & 0.311 & $\underline{0.494}$ & 0.27 & -0.036 \\
\hline System Implementation & 0.043 & -0.112 & 0.61 & 0.212 & 0.021 \\
\hline Data Integrity & -0.115 & 0.091 & $\overline{0.767}$ & -0.242 & -0.189 \\
\hline $\begin{array}{l}\text { Nonintegrated } \\
\text { applications/systems }\end{array}$ & -0.116 & 0.119 & -0.009 & $\underline{0.646}$ & -0.013 \\
\hline Too complex systems & -0.048 & -0.079 & 0.078 & $\underline{0.746}$ & -0.026 \\
\hline Spreadsheet Integrity & -0.076 & 0.046 & -0.063 & -0.214 & $\underline{0.739}$ \\
\hline Outsourcing & 0.137 & -0.107 & -0.068 & 0.143 & 0.571 \\
\hline
\end{tabular}


We validated this factor structure by mapping it to the COBIT framework. Table B2 provides top-down and bottom-up mappings. Three issues are noteworthy. First, the top-down mapping indicates that the five IT material weakness categories derived in the factor analysis map reasonably well with the four high-level IT process domains: Plan and Organize, Acquire and Implement, Deliver and Support, and Monitor and Evaluate. This suggests that our five IT material weakness categories provide adequate coverage of the COBIT framework. Second, the bottom-up mapping suggests that considerable overlap (in terms of IT-related activities) occurs across the COBIT framework's high-level IT process domains. The further analysis summarized as Table B3 corroborates (via COBIT's indication of how IT process components serve as input to other IT process components) this overlap. This overlap is indicative of an inherent difficulty, if not impossibility, in deriving a "clean" one-to-one mapping of SOX 404 IT material weaknesses from existing frameworks, such as the COBIT framework. Third, the COBIT framework is largely silent with regard to the derived IT Control Oversight-External IT material weakness category, most notably with regard to spreadsheet development/use by an organization's non-IT professionals. Nonetheless, explicit statements of IT problem areas associated with the use of spreadsheets in the processing of financial transaction processing and reporting were quite evident in the collected SOX 404 reports.

Finally, the third column of Table B4 provides a mapping of these five IT material weakness categories to the three IT management responsibility domains (global, demand-side, and supply-side) applied in developing Hypothesis 3 and Hypothesis 4. Justifications (see the fourth column of Table B4) for this mapping refer to explanations developed earlier regarding senior executive responsibilities regarding these three IT management responsibility domains.

\begin{tabular}{|c|c|c|c|}
\hline $\begin{array}{l}\text { IT Material } \\
\text { Weakness } \\
\text { Categories }\end{array}$ & Description & $\begin{array}{l}\text { Top-Down Mapping } \\
\text { to COBIT High- } \\
\text { Level Process } \\
\text { Domains }\end{array}$ & $\begin{array}{l}\text { Bottom-Up Mapping to } \\
\text { COBIT Component IT Processes }\end{array}$ \\
\hline $\begin{array}{l}\text { IT Control } \\
\text { Oversight- } \\
\text { Internal }\end{array}$ & $\begin{array}{l}\text { Ensuring that proper internal } \\
\text { controls have been established } \\
\text { for financial information systems } \\
\text { and associated technology } \\
\text { services. }\end{array}$ & $\begin{array}{l}\text { Monitor \& Evaluate } \\
(\mathrm{ME})\end{array}$ & $\begin{array}{l}\text { PO4: IT Processes, Structure \& Relationships } \\
\text { PO6: Internal Control Aims \& Directions } \\
\text { PO9: IT Risk Framework } \\
\text { DS4: Ensure Continuous Service } \\
\text { DS5: Ensure Systems Security } \\
\text { DS12: Manage Physical Environment } \\
\text { ME1: Monitor \& Evaluate IT Performance } \\
\text { ME2: Monitor \& Evaluate Internal Control } \\
\text { ME3: Ensure Compliance with External Requirements } \\
\text { ME4: Provide IT Governance }\end{array}$ \\
\hline IT Capability & $\begin{array}{l}\text { Ensuring that appropriate } \\
\text { capabilities (e.g., employees' } \\
\text { knowledge, work practices and } \\
\text { processes, etc.) exist to analyze, } \\
\text { design, build, implement, operate } \\
\text { and maintain financial information } \\
\text { systems and associated } \\
\text { technology services. }\end{array}$ & $\begin{array}{l}\text { Acquire \& Implement } \\
\text { (AI) } \\
\text { Deliver \& Support } \\
\text { (DS) }\end{array}$ & $\begin{array}{l}\text { PO7: IT Human Resources } \\
\text { Al1: Identify Automated Systems } \\
\text { Al3: Acquire \& Maintain Technology Infrastructure } \\
\text { Al6: Change Management } \\
\text { DS3: Manage Performance and Capacity } \\
\text { DS8: Manage Service Desk } \\
\text { DS11: Manage Data } \\
\text { DS13: Manage Operations }\end{array}$ \\
\hline $\begin{array}{l}\text { Software } \\
\text { Development }\end{array}$ & $\begin{array}{l}\text { Ensuring the effective design, } \\
\text { development, testing, installation, } \\
\text { and maintenance of financial } \\
\text { information systems and } \\
\text { associated data. }\end{array}$ & $\begin{array}{l}\text { Acquire \& Implement } \\
\text { (Al) }\end{array}$ & $\begin{array}{l}\text { PO10: Manage Projects } \\
\text { AI2: Acquire \& Maintain Application Software } \\
\text { Al7: Install \& Accredit Solutions } \\
\text { DS7: Educate \& Train Users }\end{array}$ \\
\hline IT Architecture & $\begin{array}{l}\text { Ensuring that enterprise and } \\
\text { technology architectures exist to } \\
\text { rationalize and integrate an } \\
\text { organization's portfolio of } \\
\text { information systems. }\end{array}$ & $\begin{array}{l}\text { Plan \& Organize } \\
\text { (PO) }\end{array}$ & $\begin{array}{l}\text { PO2: Information Architecture } \\
\text { PO3: Technology Direction }\end{array}$ \\
\hline $\begin{array}{l}\text { IT Control } \\
\text { Oversight- } \\
\text { External }\end{array}$ & $\begin{array}{l}\text { Ensuring that proper controls } \\
\text { have been established for finan- } \\
\text { cial information systems and } \\
\text { associated technology services } \\
\text { developed and/or operated by } \\
\text { entities other than an organiza- } \\
\text { tion's internal IT function. }\end{array}$ & $\begin{array}{l}\text { Monitor \& Evaluate } \\
(\mathrm{ME})\end{array}$ & $\begin{array}{l}\text { A15: Procure IT Resources } \\
\text { DS2: Manage Third-party Services }\end{array}$ \\
\hline
\end{tabular}




\begin{tabular}{|c|c|c|c|c|c|}
\hline $\begin{array}{l}\text { IT Material } \\
\text { Weakness } \\
\text { Categories }\end{array}$ & Bottom-Up Mapping & $\begin{array}{l}\text { Plan \& } \\
\text { Organize }\end{array}$ & $\begin{array}{l}\text { Acquire \& } \\
\text { implement }\end{array}$ & $\begin{array}{l}\text { Deliver \& } \\
\text { Support }\end{array}$ & $\begin{array}{l}\text { Monitor \& } \\
\text { Evaluate }\end{array}$ \\
\hline $\begin{array}{l}\text { IT Control } \\
\text { Oversight - Internal }\end{array}$ & $\begin{array}{l}\text { PO4: IT Processes, Structure \& Relationships } \\
\text { PO6: Internal Control Aims \& Directions } \\
\text { PO9: IT Risk Framework } \\
\text { DS4: Ensure Continuous Service } \\
\text { DS5: Ensure Systems Security } \\
\text { DS12: Manage Physical Environment } \\
\text { ME1: Monitor \& Evaluate IT Performance } \\
\text { ME2: Monitor \& Evaluate Internal Control } \\
\text { ME3: Ensure Compliance with External } \\
\text { Requirements } \\
\text { ME4: Provide IT Governance }\end{array}$ & $\begin{array}{l}X^{a} \\
X \\
X \\
X \\
X \\
X \\
X \\
X \\
X \\
X\end{array}$ & $\begin{array}{l}X \\
X \\
X\end{array}$ & $\begin{array}{l}X \\
X \\
X \\
X \\
X \\
X\end{array}$ & $\begin{array}{l}\text { X } \\
X \\
X \\
X \\
X \\
X \\
X \\
X \\
X \\
X\end{array}$ \\
\hline IT Capability & $\begin{array}{l}\text { PO7: IT Human Resources } \\
\text { Al1: Identify Automated Systems } \\
\text { AI3: Acquire \& Maintain Technology } \\
\text { Infrastructure } \\
\text { Al6: Change Management } \\
\text { DS3: Manage Performance and Capacity } \\
\text { DS8: Manage Service Desk } \\
\text { DS11: Manage Data } \\
\text { DS13: Manage Operations }\end{array}$ & $\begin{array}{l}X \\
X \\
X \\
X\end{array}$ & $\begin{array}{l}X \\
X \\
X \\
X \\
X \\
X \\
Y \\
Y\end{array}$ & $\begin{array}{l}X \\
Y^{b} \\
X \\
X \\
Y \\
X \\
X \\
X\end{array}$ & $\begin{array}{l}X \\
X \\
X \\
X \\
X\end{array}$ \\
\hline $\begin{array}{l}\text { Software } \\
\text { Development }\end{array}$ & $\begin{array}{l}\text { PO10: Manage Projects } \\
\text { Al2: Acquire \& Maintain Application Software } \\
\text { AI7: Install \& Accredit Solutions } \\
\text { DS7: Educate \& Train Users }\end{array}$ & $\begin{array}{l}X \\
X\end{array}$ & $\begin{array}{l}X \\
X \\
X \\
X\end{array}$ & $\begin{array}{l}X \\
X \\
X\end{array}$ & $\begin{array}{l}\mathrm{X} \\
\mathrm{x} \\
\mathrm{X}\end{array}$ \\
\hline IT Architecture & $\begin{array}{l}\text { PO2: Information Architecture } \\
\text { PO3: Technology Direction }\end{array}$ & $\begin{array}{l}\mathrm{X} \\
\mathrm{X}\end{array}$ & $\begin{array}{l}\mathrm{X} \\
\mathrm{X}\end{array}$ & $\begin{array}{l}\mathrm{X} \\
\mathrm{X}\end{array}$ & \\
\hline $\begin{array}{l}\text { IT Control } \\
\text { Oversight-External }\end{array}$ & $\begin{array}{l}\text { Al5: Procure IT Resources } \\
\text { DS2: Manage Third-party Services }\end{array}$ & $x$ & $\begin{array}{l}\mathrm{X} \\
\mathrm{X}\end{array}$ & $\bar{X}$ & $\begin{array}{l}\mathrm{Y} \\
\mathrm{X}\end{array}$ \\
\hline
\end{tabular}

${ }^{a} X$ indicates the IT process serves as a direct input to at least one of the IT processes representing a top-down IT process domains.

${ }^{\text {b}} \mathrm{Y}$ indicates the IT process serves as an indirect input (i.e., via a 'bottom-up' IT process) to at least one of the IT processes representing a top-down IT process domain. 


\begin{tabular}{|c|c|c|c|}
\hline $\begin{array}{l}\text { IT Material } \\
\text { Weakness } \\
\text { Categories }\end{array}$ & Description & $\begin{array}{l}\text { IT } \\
\text { Management } \\
\text { Responsibility } \\
\text { Domains }\end{array}$ & Mapping Justification \\
\hline $\begin{array}{l}\text { IT Control } \\
\text { Oversight - } \\
\text { Internal }\end{array}$ & $\begin{array}{l}\text { Ensuring that proper internal controls } \\
\text { have been established for financial } \\
\text { information systems and associated } \\
\text { technology services. }\end{array}$ & Demand-Side & $\begin{array}{l}\text { Fiduciary responsibilities regarding financial systems are } \\
\text { core responsibilities of the CFO (Hoitash et al. 2012; Hsu } \\
\text { and Liao 2012; Li et al. 2010; Wang 2010). }\end{array}$ \\
\hline IT Capability & $\begin{array}{l}\text { Ensuring that appropriate capa- } \\
\text { bilities (e.g., employees' knowledge, } \\
\text { work practices and processes, etc.) } \\
\text { exist to analyze, design, build, } \\
\text { implement, operate and maintain } \\
\text { financial information systems and } \\
\text { associated technology services. }\end{array}$ & $\begin{array}{l}\text { Demand-Side } \\
\text { Supply-Side }\end{array}$ & $\begin{array}{l}\text { The CFO provisions the financial expertise to determine } \\
\text { the requirements for and to assess the integrity of installed } \\
\text { financial systems (Li et al. 2010). } \\
\text { The ClO provisions the technical expertise to analyze, } \\
\text { design, build, operate and maintain financial systems } \\
\text { (Chen et al. 2011; Martin et al. 1995; Zmud and } \\
\text { Sambamurthy 2012), }\end{array}$ \\
\hline $\begin{array}{l}\text { Software } \\
\text { Development }\end{array}$ & $\begin{array}{l}\text { Ensuring the effective design, } \\
\text { development, testing, installation } \\
\text { and maintenance of financial } \\
\text { information systems and associated } \\
\text { data. }\end{array}$ & $\begin{array}{l}\text { Demand-Side } \\
\text { Supply-Side }\end{array}$ & $\begin{array}{l}\text { The CFO and the CFO's direct reports possess the } \\
\text { knowledge and experience to determine the requirements } \\
\text { for and to assess the integrity of installed financial systems } \\
\text { (Li et al. 2010). } \\
\text { The CIO and the CIO's direct reports possess the technical } \\
\text { expertise to analyze, design, build, operate and maintain } \\
\text { financial systems (Chen et al. 2011; Martin et al. 1995; } \\
\text { Zmud and Sambamurthy 2012), }\end{array}$ \\
\hline IT Architecture & $\begin{array}{l}\text { Ensuring that enterprise and } \\
\text { technology architectures exist to } \\
\text { rationalize and integrate an } \\
\text { organization's portfolio of information } \\
\text { systems. }\end{array}$ & Global & $\begin{array}{l}\text { It is the responsibility of the CEO to ensure that an organi- } \\
\text { zation's enterprise architecture (reflected in installed } \\
\text { business and technology platforms) enables, rather than } \\
\text { obstructs, significant financial system changes imple- } \\
\text { mented in support of current and future business strategies } \\
\text { (Hirschheim et al. 2010; Nadkami and Hermann 2010; } \\
\text { Smith et al. 2010).. }\end{array}$ \\
\hline $\begin{array}{l}\text { IT Control } \\
\text { Oversight- } \\
\text { External }\end{array}$ & $\begin{array}{l}\text { Ensuring that proper controls have } \\
\text { been established for financial } \\
\text { information systems and associated } \\
\text { technology services developed } \\
\text { and/or operated by entities other } \\
\text { than an organization's internal IT } \\
\text { function. }\end{array}$ & Supply-Side & $\begin{array}{l}\text { It is the responsibility of the } \mathrm{CIO} \text { to provide oversight } \\
\text { ensuring that applicable policies and procedures are } \\
\text { followed when financial information systems and the } \\
\text { technology services enabling these information systems } \\
\text { are developed and/or operated by entities other than the } \\
\text { internal IT function (Chen et al. 2011). }\end{array}$ \\
\hline
\end{tabular}




\section{Appendix C}

\section{IT Weaknesses and CIO Turnover}

\begin{tabular}{|c|c|c|}
\hline & Model $1^{\mathrm{a}}$ & Model $2^{b}$ \\
\hline IT Control Oversight-Internal & -0.051 & 0.079 \\
\hline IT Capability & 0.452 & 0.430 \\
\hline Software Development & 0.218 & 0.029 \\
\hline IT Architecture & 0.082 & 0.335 \\
\hline IT Control Oversight-External & $0.569^{\star *}$ & $0.748^{*}$ \\
\hline ClO Reporting Probability & 0.004 & 0.003 \\
\hline Number of Non-IT Weaknesses & -0.202 & -0.231 \\
\hline Size & $0.211^{* *}$ & $0.206^{\star \star}$ \\
\hline Profit & $-0.016^{* *}$ & $-0.016^{* *}$ \\
\hline Leverage & 0.086 & 0.064 \\
\hline Restatement & -0.000 & 0.006 \\
\hline Going Concern & -0.571 & -0.581 \\
\hline Growth & -0.062 & -0.065 \\
\hline Institutional Ownership & -0.439 & -0.435 \\
\hline Audit Committee Effective & -0.825 & -0.768 \\
\hline CEO as Chairman & 0.061 & 0.060 \\
\hline Board Size & -0.059 & -0.050 \\
\hline Board Independence & $1.405^{*}$ & $1.415^{*}$ \\
\hline CEO Pay Slice & -0.488 & -0.422 \\
\hline CFO Pay Slice & 3.876 & 3.807 \\
\hline Intercept & $-2.817^{\star *}$ & $-2.827^{\star *}$ \\
\hline Year Indicators & Yes & Yes \\
\hline Number of observations & 216 & 216 \\
\hline p-value for Wald Chi2 & 0.054 & 0.085 \\
\hline ROC Curve & 0.721 & 0.720 \\
\hline
\end{tabular}

andicator operationalization

${ }^{\mathrm{b}}$ Count operationalization

Note: ${ }^{* * *} p<0.01,{ }^{* *} p<0.05,{ }^{*} p<0.10$ 


\section{Appendix D}

\section{Correlation Matrix}

Table D1. CEO Turnover, Material Weakness, CIO Reporting and Turnover Probabilities (n = 546)
\begin{tabular}{|c|l|c|c|c|c|c|c|c|c|c|c|}
\hline & & $\mathbf{1}$ & $\mathbf{2}$ & $\mathbf{3}$ & $\mathbf{4}$ & $\mathbf{5}$ & $\mathbf{6}$ & $\mathbf{7}$ & $\mathbf{8}$ & $\mathbf{9}$ & $\mathbf{1 0}$ \\
\hline 1 & CEO Turnover & 1.00 & & & & & & & & & \\
\hline 2 & Number of IT Weaknesses & $\mathbf{0 . 1 3}$ & 1.00 & & & & & & & & \\
\hline 3 & Number of Non-IT Weaknesses & $\mathbf{0 . 1 4}$ & $\mathbf{0 . 2 8}$ & 1.00 & & & & & & & \\
\hline 4 & IT Control Oversight-Internal & 0.05 & $\mathbf{0 . 6 2}$ & $\mathbf{0 . 2 2}$ & 1.00 & & & & & & \\
\hline 5 & IT Capability & 0.04 & $\mathbf{0 . 3 7}$ & $\mathbf{0 . 1 0}$ & $\mathbf{0 . 2 4}$ & 1.00 & & & & & \\
\hline 6 & Software Development & 0.06 & $\mathbf{0 . 5 9}$ & $\mathbf{0 . 1 0}$ & $\mathbf{0 . 3 8}$ & $\mathbf{0 . 2 6}$ & 1.00 & & & & \\
\hline 7 & IT Architecture & $\mathbf{0 . 1 3}$ & $\mathbf{0 . 1 8}$ & -0.01 & $\mathbf{0 . 0 9}$ & $\mathbf{0 . 1 4}$ & $\mathbf{0 . 2 2}$ & 1.00 & & & \\
\hline 8 & IT Control Oversight-External & $\mathbf{0 . 0 9}$ & $\mathbf{0 . 4 2}$ & $\mathbf{0 . 2 0}$ & $\mathbf{0 . 2 5}$ & $\mathbf{0 . 1 0}$ & $\mathbf{0 . 1 2}$ & -0.01 & 1.00 & & \\
\hline 9 & ClO Reporting Probability & -0.07 & 0.01 & 0.00 & -0.01 & 0.05 & 0.04 & 0.01 & 0.06 & 1.00 & \\
\hline 10 & ClO Turnover Probability & $\mathbf{0 . 1 9}$ & $\mathbf{0 . 2 1}$ & $\mathbf{0 . 1 9}$ & $\mathbf{0 . 1 1}$ & 0.08 & 0.03 & 0.04 & $\mathbf{0 . 4 2}$ & $\mathbf{- 0 . 2 1}$ & 1.00 \\
\hline
\end{tabular}

Note: p-values of significance below 0.05 are bolded.

Table D2. CFO Turnover, Material Weakness, CIO Reporting and Turnover Probabilities (n = 518)
\begin{tabular}{|c|l|c|c|c|c|c|c|c|c|c|c|}
\hline & & $\mathbf{1}$ & $\mathbf{2}$ & $\mathbf{3}$ & $\mathbf{4}$ & $\mathbf{5}$ & $\mathbf{6}$ & $\mathbf{7}$ & $\mathbf{8}$ & $\mathbf{9}$ & $\mathbf{1 0}$ \\
\hline 1 & CFO Turnover & 1.00 & & & & & & & & & \\
\hline 2 & Number of IT Weaknesses & $\mathbf{0 . 1 2}$ & 1.00 & & & & & & & & \\
\hline 3 & Number of Non-IT Weaknesses & $\mathbf{0 . 1 7}$ & $\mathbf{0 . 2 9}$ & 1.00 & & & & & & & \\
\hline 4 & IT Control Oversight-Internal & $\mathbf{0 . 1 6}$ & $\mathbf{0 . 6 3}$ & $\mathbf{0 . 2 2}$ & 1.00 & & & & & & \\
\hline 5 & IT Capability & 0.07 & $\mathbf{0 . 4 1}$ & $\mathbf{0 . 1 1}$ & $\mathbf{0 . 2 3}$ & 1.00 & & & & & \\
\hline 6 & Software Development & $\mathbf{0 . 0 9}$ & $\mathbf{0 . 5 9}$ & $\mathbf{0 . 1 1}$ & $\mathbf{0 . 3 8}$ & $\mathbf{0 . 2 8}$ & 1.00 & & & & \\
\hline 7 & IT Architecture & -0.02 & $\mathbf{0 . 2 0}$ & 0.00 & 0.08 & $\mathbf{0 . 1 6}$ & $\mathbf{0 . 2 4}$ & 1.00 & & & \\
\hline 8 & IT Control Oversight-External & -0.03 & $\mathbf{0 . 4 4}$ & $\mathbf{0 . 1 8}$ & $\mathbf{0 . 2 5}$ & $\mathbf{0 . 1 2}$ & $\mathbf{0 . 1 2}$ & -0.01 & 1.00 & & \\
\hline 9 & CIO Reporting Probability & -0.06 & 0.00 & 0.01 & -0.01 & 0.05 & 0.04 & 0.01 & 0.06 & 1.00 & \\
\hline 10 & CIO Turnover Probability & 0.09 & $\mathbf{0 . 2 3}$ & $\mathbf{0 . 1 8}$ & $\mathbf{0 . 1 0}$ & 0.07 & 0.03 & 0.05 & $\mathbf{0 . 4 3}$ & $\mathbf{- 0 . 2 1}$ & 1.00 \\
\hline
\end{tabular}

Note: p-values of significance below 0.05 are bolded. 


\section{Table D3. CEO Turnover and Other Control Variables $(n=546)$}

\begin{tabular}{|c|l|c|c|c|c|c|c|c|c|c|c|c|c|c|c|c|c|c|}
\hline & & $\mathbf{1}$ & $\mathbf{2}$ & $\mathbf{3}$ & $\mathbf{4}$ & $\mathbf{5}$ & $\mathbf{6}$ & $\mathbf{7}$ & $\mathbf{8}$ & $\mathbf{9}$ & $\mathbf{1 0}$ & $\mathbf{1 1}$ & $\mathbf{1 2}$ & $\mathbf{1 3}$ & $\mathbf{1 4}$ & $\mathbf{1 5}$ & $\mathbf{1 6}$ & $\mathbf{1 7}$ \\
\hline 1 & CEO Turnover & 1.00 & & & & & & & & & & & & & & & & \\
\hline 2 & CEO IT Expert & 0.08 & 1.00 & & & & & & & & & & & & & & & \\
\hline 3 & Size & -0.08 & $-\mathbf{0 . 1 1}$ & 1.00 & & & & & & & & & & & & & & \\
\hline 4 & Profit & $-\mathbf{0 . 2 0}$ & $-\mathbf{0 . 2 1}$ & $\mathbf{0 . 3 6}$ & 1.00 & & & & & & & & & & & & & \\
\hline 5 & Restatement & 0.02 & 0.04 & 0.01 & -0.03 & 1.00 & & & & & & & & & & & & \\
\hline 6 & Going Concern & 0.08 & 0.07 & $-\mathbf{0 . 2 0}$ & $-\mathbf{0 . 3 9}$ & 0.04 & 1.00 & & & & & & & & & & & \\
\hline 7 & Growth & 0.01 & -0.05 & 0.01 & -0.04 & 0.02 & -0.01 & 1.00 & & & & & & & & & & \\
\hline 8 & Leverage & 0.04 & $-\mathbf{0 . 1 5}$ & 0.07 & $-\mathbf{0 . 1 8}$ & 0.04 & $\mathbf{0 . 1 4}$ & $-\mathbf{0 . 1 0}$ & 1.00 & & & & & & & & & \\
\hline 9 & Institutional Ownership & 0.03 & -0.07 & $\mathbf{0 . 4 6}$ & $\mathbf{0 . 2 5}$ & 0.06 & -0.08 & $-\mathbf{0 . 1 4}$ & 0.01 & 1.00 & & & & & & & & \\
\hline 10 & Audit Committee Effective & 0.03 & 0.02 & 0.00 & -0.06 & 0.03 & 0.02 & $\mathbf{0 . 1 2}$ & 0.03 & -0.01 & 1.00 & & & & & & & \\
\hline 11 & CEO as Chairman & $-\mathbf{0 . 1 1}$ & -0.02 & -0.01 & $\mathbf{0 . 1 2}$ & -0.04 & -0.01 & 0.00 & -0.02 & 0.00 & 0.03 & 1.00 & & & & & & \\
\hline 12 & Board Size & 0.02 & $-\mathbf{0 . 1 9}$ & $\mathbf{0 . 3 6}$ & $\mathbf{0 . 1 0}$ & -0.03 & -0.06 & $-\mathbf{0 . 1 5}$ & $\mathbf{0 . 2 0}$ & $\mathbf{0 . 0 9}$ & -0.04 & $-\mathbf{0 . 0 9}$ & 1.00 & & & & & \\
\hline 13 & Board Independence & $\mathbf{0 . 0 9}$ & 0.00 & $\mathbf{0 . 1 2}$ & $\mathbf{0 . 1 0}$ & 0.03 & 0.01 & -0.03 & 0.07 & $\mathbf{0 . 1 6}$ & 0.03 & -0.05 & $\mathbf{0 . 1 1}$ & 1.00 & & & & \\
\hline 14 & CEO Pay Slice & 0.02 & -0.07 & 0.02 & $\mathbf{0 . 1 0}$ & -0.06 & -0.06 & -0.07 & 0.02 & 0.08 & 0.01 & 0.00 & 0.09 & $\mathbf{0 . 0 9}$ & 1.00 & & & \\
\hline 15 & CEO Age & $-\mathbf{0 . 1 4}$ & $\mathbf{- 0 . 2 3}$ & 0.05 & $\mathbf{0 . 1 3}$ & 0.01 & -0.02 & 0.06 & 0.06 & -0.02 & 0.02 & $\mathbf{0 . 2 3}$ & $\mathbf{0 . 1 4}$ & -0.02 & $\mathbf{0 . 1 1}$ & 1.00 & & \\
\hline 16 & CEO Tenure & $-\mathbf{0 . 1 7}$ & $\mathbf{- 0 . 1 1}$ & 0.06 & $\mathbf{0 . 1 8}$ & -0.02 & $-\mathbf{0 . 0 9}$ & 0.00 & $-\mathbf{0 . 1 0}$ & 0.02 & -0.05 & $\mathbf{0 . 4 0}$ & 0.00 & $-\mathbf{0 . 1 4}$ & 0.02 & $\mathbf{0 . 4 1}$ & 1.00 & \\
\hline 17 & Prior CXO Turnover & -0.03 & -0.01 & 0.02 & -0.01 & 0.03 & 0.00 & -0.03 & 0.02 & 0.01 & 0.04 & 0.03 & -0.02 & 0.05 & 0.02 & -0.06 & 0.00 & 1.00 \\
\hline
\end{tabular}

Note: $p$-values of significance below 0.05 are bolded. 
Table D3. CFO Turnover and other control variables $(n=518)$

\begin{tabular}{|c|c|c|c|c|c|c|c|c|c|c|c|c|c|c|c|c|c|c|c|}
\hline & & 1 & 2 & 3 & 4 & 5 & 6 & 7 & 8 & 9 & 10 & 11 & 12 & 13 & 14 & 15 & 16 & 17 & 18 \\
\hline 1 & CFO Turnover & 1.00 & & & & & & & & & & & & & & & & & \\
\hline 2 & CFO IT Expert & 0.14 & 1.00 & & & & & & & & & & & & & & & & \\
\hline 3 & Size & 0.02 & -0.10 & 1.00 & & & & & & & & & & & & & & & \\
\hline 4 & Profit & -0.13 & -0.23 & 0.35 & 1.00 & & & & & & & & & & & & & & \\
\hline 5 & Restatement & 0.13 & 0.04 & 0.00 & -0.03 & 1.00 & & & & & & & & & & & & & \\
\hline 6 & Going Concern & 0.06 & 0.07 & -0.20 & -0.40 & 0.07 & 1.00 & & & & & & & & & & & & \\
\hline 7 & Growth & 0.04 & 0.06 & 0.01 & -0.02 & 0.01 & 0.01 & 1.00 & & & & & & & & & & & \\
\hline 8 & Leverage & \begin{tabular}{|l|}
-0.04 \\
\end{tabular} & -0.18 & 0.06 & -0.18 & 0.04 & 0.17 & -0.10 & 1.00 & & & & & & & & & & \\
\hline 9 & $\begin{array}{l}\text { Institutional } \\
\text { Ownership }\end{array}$ & -0.03 & -0.09 & 0.45 & 0.25 & 0.06 & -0.10 & -0.14 & 0.00 & 1.00 & & & & & & & & & \\
\hline 10 & $\begin{array}{l}\text { Audit Committee } \\
\text { Effective }\end{array}$ & 0.05 & -0.04 & 0.00 & -0.08 & 0.04 & 0.03 & 0.13 & 0.04 & -0.01 & 1.00 & & & & & & & & \\
\hline 11 & CEO as Chairman & -0.10 & -0.02 & 0.00 & 0.10 & -0.04 & 0.00 & 0.02 & 0.00 & 0.02 & 0.02 & 1.00 & & & & & & & \\
\hline 12 & Board Size & 0.02 & -0.12 & 0.38 & 0.10 & -0.02 & -0.07 & -0.16 & 0.20 & 0.09 & -0.02 & -0.10 & 1.00 & & & & & & \\
\hline 13 & Board Independence & -0.03 & 0.01 & 0.11 & 0.10 & 0.04 & 0.01 & -0.03 & 0.07 & 0.16 & 0.01 & -0.05 & 0.12 & 1.00 & & & & & \\
\hline 14 & CEO Pay Slice & -0.01 & -0.09 & 0.01 & 0.10 & -0.07 & -0.05 & -0.08 & 0.01 & 0.07 & 0.00 & 0.01 & 0.07 & 0.11 & 1.00 & & & & \\
\hline 15 & CFO Pay Slice & -0.04 & 0.03 & -0.07 & -0.06 & -0.01 & 0.06 & 0.03 & 0.00 & 0.02 & 0.13 & -0.08 & -0.05 & -0.03 & -0.28 & 1.00 & & & \\
\hline 16 & CFO Age & 0.00 & -0.05 & 0.13 & 0.09 & -0.02 & 0.00 & 0.02 & -0.01 & 0.09 & -0.04 & 0.04 & 0.08 & 0.05 & 0.10 & 0.03 & 1.00 & & \\
\hline 17 & CFO Tenure & -0.14 & -0.24 & 0.10 & 0.16 & -0.08 & -0.10 & -0.05 & -0.05 & 0.10 & 0.04 & 0.14 & 0.03 & -0.05 & 0.02 & 0.02 & 0.25 & 1.00 & \\
\hline 18 & Prior CXO Turnover & -0.01 & -0.02 & -0.01 & 0.02 & 0.06 & 0.07 & -0.01 & 0.08 & 0.01 & -0.02 & -0.02 & 0.01 & -0.03 & 0.00 & -0.03 & 0.00 & \begin{tabular}{|c|}
-0.01 \\
\end{tabular} & 1.00 \\
\hline
\end{tabular}

Note: p-values of significance below 0.05 are bolded

\section{References}

Beneish, M. D., Billings, M. B., and Holder, L. D. 2008. “Internal Control Weaknesses and Information Uncertainty,” The Accounting Review (83:3), pp. 665-704.

Chen, D. Q., Preston, D. S., and Xia, W. 2010. "Antecedents and Effects of CIO Supply-Side and Demand-Side Leadership: A Staged Maturity Model," Journal of Management Information Systems (27:1), pp. 231-272.

Geiger, M. A., and Taylor, P. L. 2003. “CEO and CFO Certifications of Financial Information,” Accounting Horizons (17:4), pp. 357-368.

Hirschheim, R., Welke, R., and Schwartz, A. 2010. "Service-Oriented Architecture: Myths, Realities, and a Maturity Model," MIS Quarterly Executive (9:1), pp. 37-48.

Hoitash, R., Hoitash, U., and Johnstone, K. M. 2012. "Internal Control Material Weaknesses and CFO Compensation,” Contemporary Accounting Research (29:3), pp. 768-803.

Hsu, A. W., and Liao, C. 2012. "Do Compensation Committees Pay Attention to Section 404 Opinions of the Sarbanes-Oxley Act?," Journal of Business Finance \& Accounting (39:9/10), pp. 1240-1271.

Li, C., Sun, L., and Ettredge, M. 2010. "Financial Executive Qualifications, Financial Executive Turnover and Adverse SOX 404 Opinions," Journal of Accounting and Economics (50:1), pp. 93-110.

Martin, B. L., Batcheldor, G., Newcomb, J., Rockart, J. F., Yetter, W. P., and Grossman, J. G. 1995. "The End of Delegation? Information Technology and the CEO," Harvard Business Review (73:5), pp. 161-172.

Nadkarni, S., and Hermann, P. 2010. "CEO Personality, Strategic Flexibility, and Firm Performance: The Case of the Indian Business Process Outsourcing Industry,” Academy of Management Journal (53:5), pp. 1050-1073.

Smith, H. A., McKeen, J. D., Cranston, C., and Benson, M. 2010. "Investment Spend Optimization: A New Approach to IT Investment at BMO Financial Group,” MIS Quarterly Executive (9:2), pp. 65-81.

Wang, X. 2010. "Increased Disclosure Requirements and Corporate Governance Decisions: Evidence from Chief Financial Officers in the Pre-and Post-Sarbanes-Oxley Periods," Journal of Accounting Research (48:4), pp. 885-920. 
Copyright of MIS Quarterly is the property of MIS Quarterly and its content may not be copied or emailed to multiple sites or posted to a listserv without the copyright holder's express written permission. However, users may print, download, or email articles for individual use. 